Historic, archived document

Do not assume content reflects current scientific knowledge, policies, or practices. 



\section{HORTICULTURAL IMPLEMENTS.}

Averancator, or Tree Pruning Shears, for poles, from $\$ 300$ to 600

Large size " $\quad$ " sliding eut, " " $\quad 700$ " 800

Hedge, or Box Shears................................ 175 6. 300

Lawn .. with two wheels......................

Grass Border " " plain

400

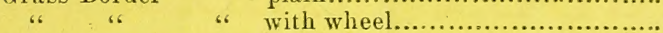

Ladies' Garden or Box Shears.

Long-Handled Lopping Shears.

Hand-Pruning Shears, serviceable for Pruning Fruit

Trees, Grape-vines, \&c

250 " 350

Hand-Pruning Shears, with sliding cut..................

Vine Scissors, for thinning out Grapes.....................

Grass Edging Knives, for paring the edges of grass....

“ Shears, with Springs................................

Flower Scissors or Gatherers, for cutting and holding the flowers

150 " 1

250 6

100

150

Pruning Scissors, bow handles.

" " sliding cut, bow handle.

Pruning Knives, Saynor's various patterns.

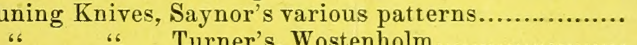

Grafting "

Budding " "

Saynor's, various patterns.

$\begin{array}{llll}00 & \text { " } & 1 & 50\end{array}$

$\begin{array}{llll}75 & \text { ، } & 2 & 00\end{array}$

Turner's, \&c.

$\begin{array}{lllll}1 & 00 & \text { " } & 150\end{array}$

Asparagus “6

100 “ 150

Pruming Saws, from 14 to 20 inch

Pruning Saws, from 14 to 20 inches.

130 “ 250

150

Pruning "6 with sockets for long handles...............

Garden Rakes, wrought iron....

300

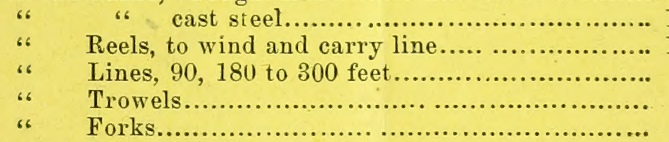

English Lawn Rakes.....................................

" Patent Rivet Back Lawn Seythes...............

" " " " Grass Hooks....................

Spading or Garden Forks.................................

Watering Pots.............................................

Garden Hoes, east steel, all sizes...........................

Dutch or Scuffle Hoes, best cast steel......................

Ladies' and Children's Garden Tools, in sets............

Green-House Syringes, of brass, Reid's Patent, with

two extra rose attached, ball valve. $.1000 \quad 61200$

Green-House Syringes, brass, for ladies.

500 “ 600

" " " " tin, brass tops and valves.........

Brier and Bill Hooks.

125

" Scythes..............................................

Welsh Scythe Stones.

150 " 250

225

Daisy Grubs

75. Dock Extractors

50 " 125

100 “ 175

100 “ 175

65 "6 300

35 “ 150

40 "“ 125

300 “ 500

$\begin{array}{llllll}1 & 75 & * & 2 & 50\end{array}$

80 " 100

125 " 225

00 " 300

40 “ 100

60 “ 150

Dibbles for Transplanting. 


\section{DREER'S}

GARDEN CALENDAR

FOR

\section{7.}

DESIGNED TO FURNISH BRIEF DIRECTIONS

FOR THE

CULTIVATION AND MANAGEMENT

OF THE

\section{VEGRTABLE, FLOWER AND FRUTT GARDEN.}

IILUSTRATED WITH WOOD CUTS,

CONTAINING

SELECT LISTS OF SEEDS AND PLANTS.

HENRY A. DREER,

SEEDSMAN AND FLORIST, No. 714 CHESTNUT STREET, PHOLADELPHDA. 


\section{DIREOTIONS TO CORRESPONDENTS.}

Much trouble, delay, and disappointment, may be avoided by observing the following directions :

1st. Be particular to write your name distinctly, with Post office, County, and State: orders are frequently received without even a signature.

2d. Write out your orders legibly, in a list apart from the body of the letter, and in case of plants, specify if any varieties may be substituted when not on hand. Amateurs not conversant with the varieties will not suffer by leaving the selection to me, as I will, in such cases, make the best possible selection.

$3 \mathrm{~d}$. It is requested that explicit directions be given for marking and shipping packages. Where no specific directions are given, I shall use my best judgment as to the route and mode of conveyance; it should, however, be expressly understood, that all packages are at the risk of the purchasers after their delivery to the forwarders.

4th. All orders from unknown correspondents, must be accompanied by cash, a satisfactory reference, or instructions to Collect on Delivery by Express.

5th. Purchasers are requested to notify me promptly of any errors, which may have occurred in filling their orders, as my desire is to give entire satisfaction.

6th. For information as to the mailing of Seeds, see page 7.

In conclusion, I would state that the usual care will be observed in putting up all orders, large or small, to give full satisfaction to the purchaser, in the quality of the article, as well as in the manner of packing and forwarding. Seo lettors of commendation on third page of cover.

HENRY A DREER, 714 Chestnut St., Philadelphia, Penna. 


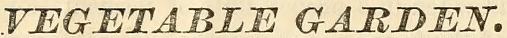

Priparation of the Ground.-To secure a fair return in scasonable crops, for the labor and outlay invested, it is essential that the soil of the Vegetable Garden should be well under-drained, thoroughly trenched or subsoiled, and enriched by a judicious application of fertilizing material. It is still the current opinion, based on experience, that for all purposes, well composted barn-yard manure, when available, is the best material. We do not deny, however, that several of the concentrated manures, now manufactured, are useful and convenient, especially for a succession of crops.

The exposure of a garden has much to do with the early maturity of the crops; an exposure to the morning sun is desirable. The soil must be in a friable state to secure the prompt vegetation of the seeds, and the destruction, or rather, prevention of weeds, is one of the most desirable results of frequent stirring of the surface. Soils are susceptible of alteration and improvement in texture; heavy clays can be rendered open and porous, and light sandy soils may be consolidated and rendered more retentive of moisture. For all such details we must refer the amateur to more extensive treatises on these subjects.

Garden Requisites.-There are several aids to the economical management of the garden, which are almost indispensable; one of these is the нот-веD frame for the forwarding of plants for early planting. A frame, such as is shown in the cut, may be made of vari-

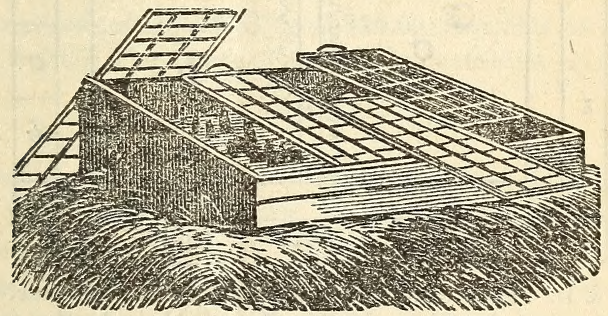

ous sizes, according to the size of garden, from four sashes upwards. The length of sash is gencrally seven feet, by three and a half wide, the size of glass six by eight inches, making the entire frame of four sashes, fourteen by seven feet. The frame should have a southern or southeastern exposure, should be made up with fresh horse manure and $a$ 
few leaves mixed with it: this must be laid in a heap preparatory to being used, and when in a proper state of fermentation, prepared for the reception of the frame. A few inches of rich loamy soil must be spread over the manure, then cover the frame with the sashes and after standing a few days to allow the rank heat and steam to pass off, the seed can be sown. Where the ground is well drained, a better plan is to dig out a space the size of the frame, from one to two feet deep, according to the season and the heat required, in which the manure is placed, care being taken to pack it firmly and evenly.

In addition to the Hot-bed frame, mats or shutters will be required to cover the sash during cold days and nights. To work the garden, the necessary implements-spade, fork, shovel, rakes, hoes, trowel, garden-line and reel, watering pot, and wheelbarrow are the most important.

Rotation of Crops. - We are convinced of the importance of a regular rotation of the Esculent crops. To convey the idea briefly, we present a diagram of the garden as laid out to secure this result.

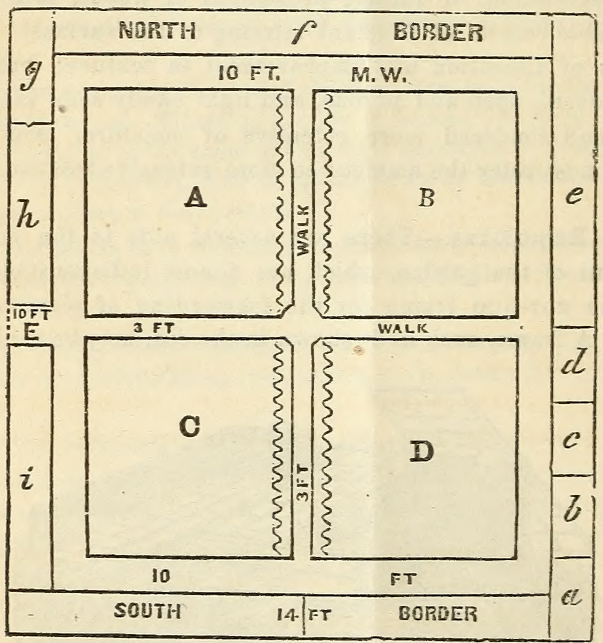

A, B, C \& D. Four compartments in which to plant various crops, alternately, $a$ to $i$., small compartments round the border for nursing plants, sweet herbs, and setting out permanent beds of Asparagus, Artichoke, Rhubarb, \&c. The border facing South, should be protected on the North side by a close board fence or wall, and will be found useful for sowing early Radish, Lettuce, Beets, \&c., and setting out Tomatoes, Egg-pl.ınts, \&c. The waved line represents a grape trellis; the entrance is at $\mathbf{E}$. This plan may be carried out in a garden of greater or less extent. 


\section{$\mathbb{E} S \mathbb{T} I$ 亚A}

\section{To Stock a Iarge Kitchen Garden}

\section{WITH A FULI SUPPLY THROUGHOUT THE SEASON.}

2 oz. Asparagus.

4 qts. Beans Dwarf or Snap.

1 " " Large Lima.

6 oz. Beet, early and late var.

1 " Borecole or Kale.

$\frac{1}{2}$ " Broccoli, Purple Cape.

$\frac{1}{2}$ “ Brussels Sprouts.

1 "Cabbage, two early var.

$\frac{1}{2}$ "6 C. Savoy.

“ Red Pickling.

“ Late Drumhead.

"Carrot, two varieties.

"Cauliflower, early.

" Celery, white and Red.

2 "Corn Salad.

1 qt. Eorn, extra early sugar.

2 qis. " "Stowell's Evergreen. 2

2 " " Large Sugar.

1 oz. Cucumber, early and late.

2 "Cress or Pepper Grass.

$\frac{1}{4}$ " Egg Plant, Large Purple.

" Endive, Curled.

"Kohlrabi, early and late.

1 “ Leek, Large Flag.
2 oz. Lettuce, three varieties.

4 " Melons, assorted.

1 "Nasturtium.

2 "Okra, Dwarf.

4 " Onion, two varieties.

4 qts. " Sets.

1 oz. Parsley, Extra Curled.

2 " Parsnip, Large Sugar.

2 qts. Peas, Dreer's Extra Early.

1 "6 "Tom Thumb.

2 " " Blue Imperial.

1 " " 6 Eugenie.

1 " " Black-eye Marrowfat.

2 " " Champion of England

2 oz. Pumpkin.

6 " Radish, early and late.

2 "Salsify, Oyster Plant.

4 " Spinach, Round Savoy.

2 "Squash, assorted.

$\frac{1}{2}$ "Thmato, two varieties.

2 "Turnips, "6 "

1 paper each: Pepper, Sage, Sweet Marjorum Thyme, Lavender, Summer Savory, Sweet Bazil.

Other varieties may be substituted, if desired.

The above assortment will cost $\$ 20.00$ : one half of the above quantities, $\$ 10.00$; one-fourth of the above quantities, $\$ 5,00$.

The following table may be useful to the gardener, in showing the number of plants or trees that may be raised on an acre of ground, when planted at any of the under-mentioned distances.

Distance apart. No. of Plants. Distance apart. No. of Plants.

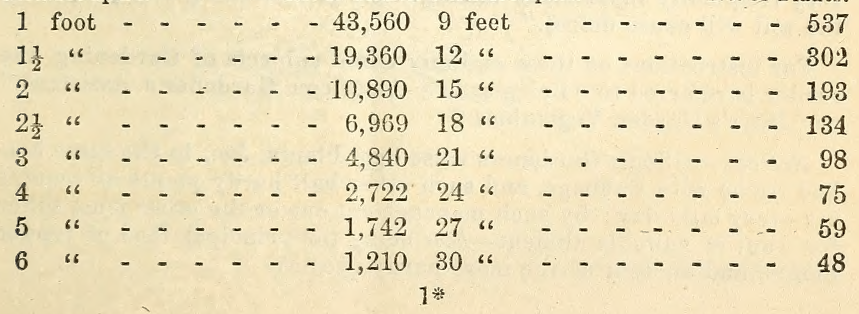




\section{Remarlss on the Failure of Seeds.}

"From a conviction that the Seedsman's fair reputation is often unjustly defamed, through the failure of seeds, we would with brevity state some of the causes:

1. That some cultivators, through ignorance or forgetfulness of the fact, that the products of a garden being natives of various soils and climates, require peculiar management, deposit their seeds in the ground at an improper season. To aid such, we have prepared brief directions, founded on practical experience in the vicinity of Philadelphia, where gardening operations are generally commenced early in March. These directions may, however, be applied to all other parts of the United States, by a minute observance of the difference in temperature.

"Thus, to the North, the directions for March will apply to April; and at the South, to January, February or whatever season gardening operations may commence in the respective States. The early and most hardy species and varieties should not be planted until the ground can be brought into good condition, as some species of plants that in an advanced stage of growth will stand a hard winter, are often cut off by a very slight frost while young, especially if exposed to the sun after a frosty night.

"2. That some species of seeds, such as Beans, Beet, Cabbage, Lettuce, Radish, Salsify, Turnip, Sc., being from their nature, apt to vegetate quickly, are often destroyed while germinating, through variableness of the weather, and some are liable to be devoured by insects in forty-eight hours after they are sown, and before a plant is seen above ground, unless a suitable remedy is applied in time to annoy the insects.

"3. That some species, as Carrot, Celery, Leek, Onion, Parsley, Parsnip, Spinach, \&c., being naturally of tardy growth taking (in unfavorable seasons) from two to three or four weeks to vegetate, are apt to perish through incrustation of the soil, or other untoward and unaccountable circumstances, which cannot always be controlled.

"4. That the failures often occur through Seeds being deposited too deeply in the ground, or left too near the surface. Sometimes, for want of sufficiency of Seed in a given spot, solitary plants will perish, they not having sufficient strength to open the pores of the earth, and very frequently injudicious management in manuring and preparing the soil will cause defeat."

For instructions on these and any other subjects of Gardening, the reader is referred to "Bridgeman's American Gardener's Assistant," or "Burr's Garden Vegetables."

Extract.-_Some Gardeners raise Egg Plants, \&c., in the same hotbed frame with Cabbage, and such other half hardy plants as require air every mild day; by such management one or the other must suffer for want of suitable aliment-heat being the principal food of tender plants, and air that of the more hardy species. 
"In the sowing of seeds, remember that in unity there is strength, and that from the germinative parts of a Seed being weak and diminutive, it cannot be expected to perforate through the soil solitarily and alone. To insure a fair chance, plant your seeds moderately thick, and thin out the surplus plants while young. In planting Seeds in drills, which is the most eligible plan, the size of the Seed and strength of its germ should be considered; large seeds producing vigorous roots, require deeper planting than diminutive Seeds, producing delicate roots and slender stocks.

\section{SEEDS BY MAII.}

Under the new Postal law, Seeds, cuttings, bulbs, \&c., can be mailed in paper packages not exceeding four pounds in weight, at the rate of "two cents for each four ounces or fraction thereof: this arrangement offers great facilities to persons residing at a distance of procuring reliable and pure Seeds, at a very trifling cost for transportation, as we will mail all orders for Seed in papers or by the ounce,) Beans, Peas, and Corn excepted,) amounting to one dollar or upwards, free of postage charges. When ordered by the pound or quart, eight cents additional per lb. or fifteen cents per qt. must be added to the price of the Seeds. A postage stamp must accompany all orders under one dollar.

To insure prompt attention, a remittance must accompany the order. Correspondents will please write out their names legibly, with Post Office, County, and State.

\section{Descriptive List of Vegetable Seeds.}

For the convenience of purchasers the Seeds are put up in papers of five, ten, and twenty-five cents each. Those quoted at thirty cents per ounce and upwards, in not less than ten cent papers.

French, Spanish, and German names follow after the English, to each class of vegetables.

\section{ARTIOHOKE.}

Artichaut, Fr. Alcachofa, Spas. Artischoken, GER.

Large Green Globe, per oz. 50 cts.

Plant the seeds early in April, in rich soil, in $d$ :ills one inch deep, and about twelve inches apart. When one year old transplant in wellmanured ground, in rows fire feet apart, and two feet from plant to plant. Protect during the winter by throwing up ridges of earth, and covering with manure or leaves.

\section{ASPARAGUS,}

Asperge, Fr. Esparrago, Span. Spargel, GER.

Large Green, per oz. 10 cts. Lesher's Mammoth, per oz. 20 cts.

Sow in March or April, in rich soil. Soak the seed in warm water for 24 hours. Drill it thinly in rows a foot apart. When two vears old, transplant into permanent beds, which should be well and deeply manured. Make the beds four feet wide. Set out the plants twelve inches apart each way, and four inches deep. On the approach of 
winter clear off the bed, and cover with a dressing of manure, or compost; fork up the beds early in the spring, and apply a dressing of salt annually to the bed, after the season of cutting-which is not only beneficial to the plants, but will keep the bed clear of weeds.

\section{BEANS, -English Dwarfs.}

\section{Feve de Marais, Fr. Haba, Span. Puffbohnen, Ger.}

Early Mazagan, per qt. 40 cts. Green Lona Pod, per qt. 40 cts. Broad Windsor, "6 " 40 " Horse, " 40 "

To succeed well, these must be planted early, as the summer heat causes the blossoms to drop off prematurely, being quite hardy. Plant early in March, in strong loamy soil, in drills two feet apart.

\section{BEANS,-Dwari, or Snap-Short.}

\section{Haricot, Fr. Frijoles, Span. Buschbohnen, Ger.}

Early Mohawk, per qt. 40 ets. White Kidney, per qt. 30 cts. Early China Red Exe, 30 “ Refugee, 40 “ Eariy Yellow Six Weeks, 40 " Newington Wonder, 40 " Red Speckled Valentine, 50 " Turtle Soup, Black " 30 " Red French or Marrow, 40 " White Marrowfat, 30 "

The above list contains all that are really desirable.

All the varieties of this class are tender and will not bear the cold. The Mohawk is considered the hardiest, and is generally the first planted. The Valentine and Newington Wonder, are, however, the favorite varieties in this market, the pods being round and stringless. Plant about the middle of April, and at intervals throughout the season, for a succession, finishing about the end of July. The best mode of culture is in rows two feet apart and the beans two or three inches apart. Keep well hoed and draw the earth up to their stems.

\section{BEANS, Pole or Running.}

\section{Haricot a rames, Fr. Stangen Böhren, GER.}

Large Lima, per qt. 60 ets. Cranberry, per qt. 50 cts. Carolina Lima, " "6 " 60 " " " 50 " Scarlet Runner, "6 60 "6 German Wax, " " 80 " White Dutch Runner, 50 “ Dutch Case Knife, " 00 “

New Giant Wax Bean, per paper, 25 cts.

Plant about the middle of May. The Lima Beans are very susceptible of cold and wet, and apt to rot in the ground, and should not be planted until the season is favorable and the ground warm. Fix poles in the ground, four feet apart each way, and plant four to six beans about an inch deep around each pole. A shovel-full of rich, light and well rotted compost to each hill would be beneficial. They may be forwarded much earlier by sprouting them in a frame, under glass, and planting them out when the weather becomes mild, as they bear transplanting without any difficulty. The Horticultural and German Wax Bean are superior varieties, either as snap shorts or shelled. 
BEET, 10 cts. per oz.

Betierave, Fr. Bettaraga, Span. Rothe oder Runkel rübe, Ger.

Extra-Early Bassano.

Simon's Ex. Early RED.

EARLY BLOOD-RED TURNIP.

Half Long Blood.

LONG BLOOD-RED.
LoNG SMOоTH BLOOD, or (RADISH Shaped.)

Swiss Chard,

Silesian, or Surarar.

Long Red Mangel Wurtzel.

Yellow Globe Mangel Wurtzel.

The first five named, are esteemed the best for table use. Sow in drills from April to June; thin out the plants to stand six or eight inches apart in the drills. The leaves of the Swiss chard are used as Spinach and the mid-rib of leaf dressed as Asparagus. The last three named varieties are used principally for feeding stock, and where extensively grown, the rows should be wide enough apart to cultivate with a horse hoe.

\section{BORECOLE. \\ Chou vert, Fr. Berza, Span. Kohl, Ger.}

Dwarf German Kale, per oz. 10 Scotch Kale, per oz. 15 cts Tall German Kale, “ 25 Red, or Purple Kale, “ 25 "

An excellent green for Winter and Spring use. Sow from May to June. Set out the plants in July, in good rich ground. For early Spring use, sow the Dwarf German, in September, and protect over Winter, with a covering of Straw or litter.

\section{BROCCOLI.}

Brocoli, Fr. Broculi, Span. Spargel Kohl., Ger.

Earlu Purple Cape, per oz. 75 cts. Early White Cape, per oz. 1.00.

Produce heads in Autumn like Cauliflower. The Cape varieties are best adapted to our climate. Sow about the middle of May, transplant and manage as Winter Cabbage.

\section{BRUSSELS SPROUTS, 30 cts. per oz.}

Chou de Bruxelles, Fr. Rosenkohl, GER.

Produces from the stem small heads, resembling Cabbage in miniature. The sprouts are used as winter greens, and become very tender when touched by the frost. Sow in May, transplant, and manage as winter Cabbage.

\section{CARDOON.}

Cardon, Fr. Cardo, Span. Kardonen, Ger.

Large Solid Stalked, per oz. 60 cts.

Is much cultivated in Europe for culinary purposes. The stem of the leaves, which are thick and crisp, after being blanched, are the eatable parts, and are generally used in soups or stews. They are in perfection during the autumn and winter. Sow in April; and transplant in trenches of well manured ground; blanch by earthing up in the fall. 


\section{CABBAGE.}

Chou Pontme, Fr. Repollo, Span. Kopf. Kohl, Ger.

EARly. York, per oz. 25 cts. Red Drumhead, per oz. 50 cts.

Early Oxheart, " "40 "Red Dutch for Pickling, 30 "

Early Sugar Loaf, " 30 " Large Late Drumhead, 50 "

Wheeler's IMPerial, " 40 " Large Flat Dutch, "

Large Early York, " 30 " Large Bergen, " 30 "

Early Winnigstadt, " 50 " Early Dwarf Savoy, "30"

Early Battersea, " 30 " Green Curled Sayot, 30 "

Early St. John's Day, " 30 " Large Drumhead Savot, 30 "

The first column contains the early sorts, which may be raised as follows: Sow the seed in well prepared ground, about the 15th of September. When the plants are large enough to transplant, pick them out of the seed bed, into frames. Protect the plants during severe weather, with a covering of boards, observing to give them plenty of air and light during mild weather. They may also be raised by sowing the seed very early in thespring, in hot-beds-afterwards plant out in deep and well-manured ground, in rows eighteen inches apart and twelve inches distant in the rows.

The autumn and winter sorts, sow in April or early in May, in a moderately shaded border, in shallow drills, three or four inches apart.

Transplant early in July, in rows thirty inches apart, and about two feet apart in the rows. Cabbage succeeds best in a fresh, rich soil, well manured and deeply dug or plowed. The late plants are subject to attacks of the cabbage fly, destroying them as fast as they appear above ground. Various remedies are recommended for the preservation of the plants, such as sprinkling them with ashes, air-slack lime, plaster, or tobacco, which should be performed early in the morning. A solution of whale-oil soap is also recommended.

\section{CAUIIFLOWER.}

Chou Fleur, Fr. Coliflor, Span. Blumen Kohl, Ger.

Early London, per oz. $\$ 1.00$ Large Walcheren, per oz. $\$ 1.00$ Early Paris, "2,00 Late Statholder, "6 1.00 Early Erfurt, Dwarf, " 2.50 Large Le Norifand, “ 2.00

Sow for early about the middle of September, in a bed of clean rich earth. In about four or five weeks afterwards the plant should be pricked out into another bed, at the distance of four inches from each other every way: these should be encompassed with garden frames, covered with glass sashes, and boards or shutters. The beds must be so secured, and the tops of the beds so covered as to keep out all frost, giving them light and air every mild day throughout the winter.

Transplant in April into a bed of the richest earth, in the garden, at a distance of two feet and a half each way. Keep.them well hoed, and bring the earth gradually up to their stems. The late variety matures in the autumn, and is sown and managed similarly to Cape Broccoli, but are not so certain to succeed in this climate. 


\section{CARROT.}

Carotte, Fr. Zanahoria, Span. Möhren, Ger.

Scarlet Short-Horn, per oz. 20 cts. Long Orange, per oz. 15 cts. Early Scarlet Horn, " 20 cts. Altringham or Field, 10 cts. HalF-Long Orange, " 20 cts. Large White Field, 10 cts.

The first three are the best kinds for table use. The Early Horn should be cultivated for spring use; but the Long Orange is more suitable for a main crop. For an early crop sow the seed, latter end of March, in well-dug, rich loamy soil, in drills about an inch deep and twelve inches apart. For late crop sow in May.

The most suitable ground for late Carrots, is that which has been well-manured for previous crops, and requires no fresh manure.

\section{CELERY.}

\section{Celeri, Fr. Appio Hortense, Span. Sellerie, Ger.}

Dreer's White Solid, per oz. 40 cts. Cole's Crystal White, 40 cts. Rose Colored Solid, " " 30 cts. Ivery's Nonsuch, Red, 40 cts. Seymour's White Solid, “ 30 cts. Celeriac, or Turnip-rooted, 30

Turner's Incomparable DWarf White, (extra,) per oz. 50 cts.

Sow the last of March or early in April, in rich mellow ground, and in a situation where the plants can be protected from the parching heat of a summer sun; in dry weather water freely. When the plants are five or six inches high, transplant a portion in trenches well manured, and repeat at intervals of two or three weeks for succession. As they advance in growth, blanch by earthing up, which should be performed gradually in fine weather, taking care not to bury the hearts of the plants. The Celeriac, or Turnip-rooted, may be planted either on level ground or in shallow drills. The root of it swells like a turnip, and may be preserved in sand through the winter; this is cooked and dressed similar to a Beet.

\section{CHERVIL, per oz. 25 cts.}

Cerfeuil, Fr. Perifolio, Span. Garten Körbel, GER.

Used as small salad, and for seasoning like parsley. Sow in drills, in sping and at intervals.

Chervil, New Parsnip-rooted, per oz. $25 \mathrm{cts}$.

\section{CHICORY-Large-rooted, per $0 z, 15$ cts.}

The roots of this variety are dried and used as a substitute for Coffee. Sow in April. Cultivate like'Carrots.

\section{CORN SALAD, per oz, 15 cts.}

Mache, Fr. Ackersalat, GER.

Used as a small salad throughout the winter and spring. Sow in drills in August and September. Cover with straw on the approach of winter. 
CORN-for Garden Culture.

Mais, Fr. Maiz, Spax. Welschkorn, Ger.

Aday's Extra Eariy, per qt. 30 cts. R. Isl. Asfluy Sweet, per qt. 40 Extra Early Stgar, " 30 " Tuscarora, 30 ets. LARge Sweet, or Sugar, " 30 " STowell's Evergreer, 25 "“

Plant about first week in May and at interrals. The above rarieties are the best for table use. Adam's Early, is the hardiest, and can be planted about the middle of April, and is the first corn that appears in the market, but cannot compare with the Sugar, or the Evergreen, which are, without question, the best for culinary purposes.

The Sugar Corn being liable to rot in cold or wet ground, shouid not be planted until May, and for a succession, continue planting erery two weeks, until the middle of July, in well-manured ground, in hills three feet apart.

\section{ORESS, per oz. 10 cts.}

Cresson, Fr. Alenois Mastuerzo, Spax. Garten Kresse, Ger. Curled, or Pepper Grass. Broad Leated Gardex. True Water Cress, per oz. 50 cts.

Csed as a small salad. Sow at intervals throughout the season. The Water Cress requires a stream of running water, in which it will grow without care, except keeping at first weeds from interfering with it.

\section{CUCUMBER.}

Concombre, Fr. Cohombro, Spax. Gurken, Ger.

Earit Russian, per oz. 30 cts. Large Early Market, per 0z. 25 cts. Early Fraie, " 25 " Long Green Terker, " 30 " Eariy White-spined, 25 "G GHerkin, or Burr, " 50 "

The first four are the earliest and most esteemed table varieties.

The White-Spined retains its green color much longer than any other variety, and is principally grown for our markets. The Lorg Green and Gherkin are mostly used for pickles. For early use, plant about first week in May, on a warm and sheltered border. For pickles plant in the middle of July.

\section{ENGLISH PRIZE CUOUMBERS.}

In packages; 25 cts. each.

Champion of England.

Sir Colin Campbeli.

General Canrobert.

Sion Hotse, Improved.

RoMAN EMPEROR.

Victory OF Bath.

Kirklex Hall Defiance.

Srow's Horticultural Prize.

Kelway's Perfection.
Giant Arnstadt.

Himalaya.

LYNCH'S Star of the WEST.

Carter's Prolific.

HAage's Giant.

Berkshire Champion.

Wright's WONDER.

Bradford Hero.

Derbyshire Hero.

These are the farorite varieties for forcing, frequently attaining a length of thirty inches. To grow them properly requires a skilful gardener, or much fuller directions than can be imparted in these pages.-See works on gardening. 
EGG-PLAIVT.

Aubergine; Fr. Berengena, Span. Eierpflanze, GrR.

Early Oval Purple, per 0z. 50 cts. Scarlet, $10 \mathrm{cts}$. per paper.

Large Round Purple, “ 60 " Lona White, 10 cts. per paper.

The first two are the kinds usually cultivated for table use-the others are fancy varieties.

Sow in hot-beds early in March; transplant middle of May to first of June, in a rich warm piece of ground about thirty inches apart.

Draw the earth up to their stems when about a foot high. Egg-plant seed will not vegetate ireely without substantial heat, and if the plants get the least chilled, in the earlier stages of growth, they seldom recover. Repeated sowings are sometimes necessary.

\section{ENDIVE, per oz, $30 \mathrm{cts}$. \\ Chicoree, Fr, Endivia, Span. Endivian, Ger.}

Green Curled,

White Curled,
Green Curled Moss, Broad-Leaved Batavian,

The Green Curled is considered the hardiest and best for salad. Sow in July, in shallow drills. When three or four inches high, transplant into good ground, at a distance of a foot apart. Blanch by tying up, which must be done when quite dry, or they will rot. At the approach of winter, the growing crop may be taken up carefully, with a ball of earth to each plant, and planted close together in a frame or dry cellar.

\section{KOHL-RABI, or Turuip-rooted Cabbage.}

Chou Rave, Fr. Kohl Rabi, GER.

Eariy White Vienna, per oz. 30 cts. Large Late Blue, per oz. 25 cts.

"BLUE " " 30 " " "WhITE, " 25 "

This is a favorite vegetable in Europe, especially on the continent, and should be grown in every garden. Sow in April, and transplant in rows, twelve to eighteen inches apart. For late use, sow in June.

\section{KALE-See Borecole.}

Sea Kale, per oz. 30 ets.

Chou Marin, Fr. Col. Marina, Span. See Kohl, Ger.

Is much esteemed in England, in some parts of which it grows spontaneously. The seed may be sown in October, or as early in the spring as the ground can be worked. For further directions see Bridgman's Kitchen Gardener's Instructor.

\section{LEEK.}

\section{Poireau, Fr. Porree, Span. Lauch, Ger.}

Large Scotch Fla

Larae Musselberg, very fine, per oz. 40 cts.

Sow early in April. When the plants are four or five inches high, transplant in rows. 


\section{LETTUOE,}

\section{Laitue, Fr. Lechuga, Span, Garten Salat, Ger.}

Early Curled, per oz. 25 cts. Paris Greex Coss, per oz. 30 cts. Early Stonehead, " 25 " Brown Detch, " 30 "

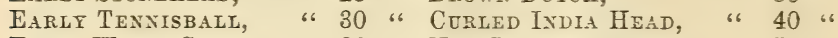
Early White Cabbage, " 30 " New Perpignan, " "50 " Royal Cabbage, " 30 " Ped Edged Victoria, " 50 " White, or Ice Coss, “ " 30 " Hardy H.immersuth. 30 "

The Early Curled is used as a cut salad, for which purpose it is sown thickly in frames, early in the spring, and somewhat later in the open borders. The Early Stonehead, is one of the earliest heading rarieties; the Early Cabbage, or Butter, is also a fine early Head Salad; the Royal Cabbage is a little later, and produces fine solid hears, and is much esteemed. The Curled India and Perpignan produce tine solir heads, and stand the heat well. To grow Head Lettuce fine, sow the seed in September; protect the plants during the winter, in frames, and plant out early in April, in rich moist ground, or sow in hot-beds in February or March, and afterwards transplant.

\section{MUSIIROOM SPAWN.}

Sold in the form of Bricks, at $50 \mathrm{cts}$. each.

Champignon, Fr. Seta, Span. Champignon brut, GER.

Culture.-Mushroom beds are best made under cover. A dry cellar or shed will do. Collect fresh horse-droppings without straw, turn them over three or four times, to get rid of the heat, dig out a foot deep of the space to contain the bed, lay some long manure at the bottom, and then the prepared dung, a little at a time, evenly and well beaten down until it is a foot abore the ground; put a layer of light earth on this, two inches thick; after a few days when the rank heat has passed off, place the spawn in the bed in lumps about $t$ wo inches square and six inches apart, then cover with light earth an inch thick; beat it gently down all over. Corer the bed thickly with siraw, and if out of doors, keep off rain, and protect from the cold with mats or koards. In about five weeks the mushrooms should make their appearance.

\section{MUSK-MELON.}

Melon Muscade, Fr. Melon Muscatel, Spar. Kantalupen, Grr. Jexir Lind, per oz. 10 cts. LARge Nutureg, per oz. 20 cts. Netrad Citron, " : 10 " Persian, (veryfine, " 25 " Pine APPJe, " 20 " W White JAPAN, " 25 "

\section{Mango, (for pickling only,) per oz. 20 cts.}

All the abore varieties can be recommended. The Jenny Lind is a small variety, and with the Citron and Pire Apple, are the lealling varieties in our market, and are of exquisite flaror; the Persian is a late variety of large size and superior quality. Plant early in May, in hills of rich light soil, six feet apart each way; allow three plants to each bill. When about a foot long, pinch off the tips, to make them branch. Observe not to plant pumpkins or squasi near them. 


\section{WATER-MELON}

\section{Melon d'Eau, Fr. Zandia, Span. Wasser Melonen, Ger.}

Mountain Sweet, peroz. 10 cts. Goodwin's Imperial, peroz. $20 \mathrm{cts}$. Mountain Sprout, " 10 " Ice Cream, true, " 20 " Black SPANish, " 10 "ORANGE, " 20 " Citron, (for preserving,) 10 "Apple Pie, " 20 "

The Mountain Sweet is cultivater extensively for the Philadelphia Market, and stands deservedly the first on our list; when well-grown from pure seed, it cannot be surpassed for size and quality. The Ice Cream, is early, of large size, pink flesh, and white seed. The Apple Pie is prepared like apples for pies and sauces; the Orange is of small size; the flesh separates from the rind like an orange, and is an excellent variety for late use. The Water-melon thrives best in a sandy soil, and should be planted in hills eight feet apart each way.

\section{MUSTARD, per oz, 10 cts. Moutard, Fr. Mostazo, Span. Senf, Ger. Wнiте, (English.) \\ Brown.}

Sown like cress and used as a small salad. The White Mustard is also used for medicinal purposes.

\section{NASTURTIUM, per 0z, 25 cts. \\ Capucine, Fr. Capuchina, SPAN. Kapuziner, Ger.}

The seed pods and foot-stalks are gathered green and pickled in vinegar; resembling capers. Sow in April or early in May.

\section{OKRA, OR GOMBO.}

Quibombo, Span. Essbarer Hibiscus, Ger.

DWARF, LONG PODDED, per oz. $10 \mathrm{cts}$.

The green capsules of this plant are used in soups, stews, \&c., to which they impart a rich flavor, and are considered nutritious. Plant the seeds about the middle of May, in hills or drills. Plant the seed thickly, as it is liable to rot in the ground; rich ground is necessary.

\section{ONION.}

Ognon, Fr. Cebolla, Span. Zwiebel, Gre.

White, or Silver Skinned, per oz. 40 cents.
Large Yellow Strasbura, per oz. 30 cents.

LARge Wethersfield, per oz. 25 cents.

The Silver Skin and Yellow Strasburg are grown in this vicinity, as northern grown seed cannot be depended upon to raise good sets. For sets, sow the seed early in the Spring, very thickly, in beds or drills. As soon as the tops die off in the summer, remove them to a dry airy place; and early in the following Spring re-plant in rows about four inches apart, the rows wide enough apart to admit of hoeing. The Onions, by this process are obtained of a large size early in the season. They may be reared to full size during the first season, by sowing in drills early in March, in strong land, and thinning them out to stand two or three inches apart, keeping them well hoed: for this purpose the Red Wetbersfield is usually preferred. 
WHITE

\section{ONION SETS,}

Plant early it the Spring, in rich ground, in drills six inches apart.

\section{PARSLEY.}

Persil, Fr. Perejil Span. Petersilie, Ger.

Corled, or Double, per oz. $10 \mathrm{cts}$. Extra Curled, per oz. $20 \mathrm{cts}$. Sow early in April, in rows. Soak the seed first in warm water.

\section{PABSNIP, per oz. 10 cts.}

Panais, Fr. Chariberia, Span. Pastinake, Ger.

Large Sugar, or Hollow-Crowned.

This is decidedly the best variety. Sow early in April, in rich ground, well dug. Cultivate similar to carrots. The roots can remain in the ground for spring use.

\section{PEAS,}

Pois, Fr. Guizante, Span. Erbsen, Ger.

Earliest.

DREER'S EXTRA EARLY, very early and prolific, Height. Price per qt.

Extra EARLY, . . . . . . . $2 \frac{1}{2}$ "

Daniel O'Rourke, an early English variety, . $2 \frac{1}{2}$ " $\quad .40$

Dillistone's Early Prolific, • . . $2 \frac{1}{2}$ “

TOM THUMB, or Allen's Dwarf, . . . 10 inches, $\quad .80$

The Tom Thumb, is the best Early Dwarf Pea; requires a rich soil, and is well suited from its dwarf habit for small gardens; a good bearer.

Second Early.

Early Frame, or Washington, - . - . 3 feet. Price per qt.

BISHOP'S DWARF, prolific, • • • • $1 \frac{1}{2}$ “ $\quad .50$

Bishop's New Long Podded DWARF • • . $1 \frac{1}{2}$ “ $\quad .50$

*Advancer, new and fine, . . . . . . 2 " 4

For General and Late Crops,

*CHAMPION OF ENGLAND, (one of the best,) 3 “ 50

Champion of Paris, . . . . . 4 " 4 " 50

DWARF BLUE IMPERIAL, a favorite variety, $2 \frac{1}{2}$ " " 40

*Veitche's Perfection, very fine, • . . $2 \frac{1}{2}$ “

Waterloo, or Victory Marrow, . . . 6 " 6

*HAIR'S DWARF GREEN MARROW, fine, $2 \frac{1}{2}$ “ $\quad .60$

White Marrowfat, . • . • . . . 3 “ 30

Black-eye Marrowfat, • • • • . 3 “ 30

*NApoleon, or new Dwarf Climax, . . . $2 \frac{1}{2}$ “ $\quad .60$

*EUGENIE, or Alliance, • • • • . 2 " $\quad .60$

DWarf Stgar, edible pods, (true) • • . 2 " 1.00

TALL, " " " . . 4 to 6 " 1.00

*Knight's Dwarf Green Marrow, . • . ” “ “

*Knight's Tall Green Marrow, . . . . 5 “

Those marked thus * are wrinkled marrows, the finest flavored 0 peas.

The above list contains all the leading varieties, and is quite sufficient to suit all purposes. 
Commence planting the early kinds as early in the Spring as the ground can be brought into good condition. All the other sorts will answer for successive crops. To have Peas during the Summer and Autumn plant in June, July and August, in single or double rows, from two to four feet apart, according to height. Dreer's Extra Early is one of the best for early as well as late planting, and is extensively used by our market gardeners for a late fall crop. In hoeing, draw the earth up to their stems.

\section{PEPPER.}

Piment, Fr. Pimento, Span. Pfeffer, Ger.

Large Sweet Beli, per oz. 50 cents.Cayenne, or Long, per oz. $\$ 1.00$ Tomato-Shaped, per oz. $50 \mathrm{cts}$. Cherry,

The Bell-Shaped and Tomato are used, when green, for pickling. The Bell-Shaped is quite mild, and attains a large size. Sow in hotbeds in March, or on a warm border early in May. Transplant in good rich ground, from 18 to 24 inches apart.

\section{PUMPKIN.}

Courge, Fr. Calabaza, Span. Kuerbis, Ger.

Cashaw, (Crooked-necked) $10 \mathrm{cts}$. Larae Chense, per oz. $10 \mathrm{cts}$. Mammoth, per oz. 50 " Field, per qt. 30 cts.

Plant in May in hills, eight or ten feet apart each way. The Cashaw is generally preferred for cooking.

\section{RADISH, 15 cts, per oz,}

Radis et Rave, Fr. Rabano, Span. Rettig, Ger.

Early Scarlet Olive Shaped,

EARLY WHITE " "

Long Scarlet Short Top.

Lona Salmon "“ "

White TURNIP-Rooted:

RED TURnip-rooted, or Cherry.

Yellow Turnip, or SumMer.

White Naples, or SUMMer.

White Spanish, or Winter.

Brack Spanish, or Winter.

Scarlet China Winter, $25 \mathrm{cts}$. oz.

The first column contains the varieties used for early sowings, which should be made as early in the Spring as the ground can be worked, on a sheltered border. The ground should be well manured, dug and raked. The Yellow Turnip and White Naples are excellent varieties for Summer use.

\section{RHUBARB, per oz, 25 cts.} Rlubarbe, Fr. Ruibarbo, SPan. Rabarber, Ger. VICTORIA, LiNNEUS, Prince Albert, Magnum Bonum.

The stalks of this plant are used for pies and tarts. It is fit for use before green fruit appears, and is an excellent substitute. Sow in April; transplant the ensuing Autumn or Spring to any desired situation, in deep and heavily manured ground. As no dependence can be placed upon growing the varieties truely from seed, it is recommended to those who desire a choice article, to procure the roots. We offer the following choice varieties. 


\section{RHUBARB ROOTS.}

25 conts each; $\$ 2$ to $\$ 1$ per dozen, actording to size. These are not seedlings, but propagated from the true varieties.

Mitchell's Early.
Mrati's Linnaus.
Myatt's Victoria.

Prince Albert.

Royal Leamington.

Magnum Bonum.

To grow the stalks to perfection, the ground must be dug and heavily manured, at least two feet deep. Set out the roots four feet apart each way.

\section{SALSIFY, OR OYSTER PLANT, per 0z. 25 cts.}

Salsifis, Fr. Salsifi, Span. Haferwurzel, GER.

A fine vegetable used as carrots; or, after being boiled, made into cakes with paste, and fried like oysters, which they resemble in flavor. Cultivate same as parsnips; it is also hardy and can remain in the ground all Winter for early Spring use.

\section{SCORZONERA, per oz. 30 cts.}

Scorsonere, Fr. Escorzonera, SPAN. Schwartz wurzel, GER.

Known as Black Salsify. It is cultivated and used in the same manner as the Salsify.

\section{SORREL, (Garden) per oz, 20 cts.}

Oseille, Fr. Acedera, Span. Sauerampfer, GER.

Used as a salad. Sow in April in shallow drills; thin out the plants to twelve inches apart.

\section{SPINACH,}

$10 \mathrm{cts}$. per oz. $-80 \mathrm{cts}$. per $\mathrm{lb}$.

Epinard, Fr. Espinaca, Spav. Spinat, Ger.

RouNd-LEaved SavoY. New Zealand, per oz. 20 cts.

For Spring and Summer use, sow as early as the ground can be worked. For Winter and early Spring use, sow in September, in well manured ground; cover with straw on the approach of cold weather.

\section{SQUASH.}

\section{5 cts. per $0 z$.}

Courge, Fr. Calabasa, Span. Kürbis, Ger.

Earit Bush, or Pattr Pan.

Early Golden Bush.

Long Green Crook-neck.

Turban, per oz. 40 ets.

BOston MarRow, $20 \mathrm{cts}$.

New HubBard, 20 cts.

The varieties of the first column, are the best for summer use, and the Boston Marrow and Hubbard, are superior Winter varieties. The Early Bush appears to be the favorite variety for summer use, as it is more extensively grown than any other, and being of a bushy habit, is more suitable for small gardens than the running kinds. Plant in hills in the same manner, and at the same time, as Cucumbers and Melons. The bush varieties three or four feet apart, and the running kinds from six to nine. 


\section{TOMATO.}

Tomate, Fr. Tomats, Span. Liebes Apfel, Ger.

Extra Early Red, per oz. 50 cts. Fejee Island, per oz. 50 cts.

LARGe SMOOTh Red, “ 25 “ LARGE YeLLOW, “ 50 “

The Cook's Favorite, new, 50 “ Red and Yellow Cherry, 50 cts.

TILDEN, new, the most solid, smooth, and fine-flavored variety. Price, 25 cts. per paper; per oz. $\$ 1.00$.

The Eztra Early is desirable only for ripening a few days in advance of the other varieties. The Tilden is now the popular sort, both for early and late use. The fruit is of good size, solid, and fine-flavored. The Cook's Favorite, also a solid, smooth variety, medium size. The Fejee Island, large size, solid, and good flavor, but later in ripening than the other sorts. These three varieties can be recommended as the best for general cultivation, or family use; for putting up in cans for winter use they have no superior, as they contain less water and seeds than other varieties. For early use sow in hot beds, or boxes, early in March, and plant out in Miay, from four to five feet apart. For late use set out the plants in July; the green fruit can be picked off before frost, and ripened under glass.

TURNIP, per oz. $10 \mathrm{cts}$. Navet, Fr. Nebo, Span. Ruben, Ger.

White Fiat Dutch, strap-leaved. Long White French.

Purple or Red Top, “ “ Yellow Aberdeen, or Scotch.

Teltow or Marrow, per oz. 20 cts. Purple Top Ruta Baga.

Robertson's Golden BaLl.

Early Yellow Stone.

White NorfolK or Globe.

Golden Globe Ruta Baga.

White Ruta Baga, or Swedish.

DALE'S HYBRID.

The first four on the list are the best for table use: the Flat Dutch is usually sown for early summer use, quite early in the Spring, and also with the Purple Top in July and August, for a main crop. Robertson's Golden Ball is of recent introduction, and is highly recommended for culinary purposes. So is also the Teltow, a small, delicate-flavored variety, highly esteemed in Germany. The Globe, Norfolk, and Ruta Baga, are principally used for feeding stock. Sow in June, or early in July, in drills two feet apart, and thin out to stand six inches apart-keeping the ground well stirred and clear of weeds. As Turnips are grown principalIy for consumption during the winter and early spring, a few brief hints for their preservation is necessary. Take up the roots in November, cut off the tops within an inch of the crown. Those for winter use can be stored away in a cool cellar or pit, and covered over with a few inches of dry earth. For early spring use, pile up in conical form, out of doors, cover carefully with long straw, and finish by earthing up, covering them with about 12 or 15 inches of earth; leave a vent or air-hole, by placing a bunch of straw in the top. Put away in this manner, they will be found in good condition in the spring. 


\section{AROMATIC, SWEET AND MEDICINAL HERBS.}

Per paper, 10 cts.

ANIsE。

ANGELICA.

BAsIL, sweet.

*Barm.

Celery, for flavoring. * Mint.

Castor Oil Bean.

Cunin.

*Dirl.

Balsam Apple.

Burnet.

BelladonNa.

Bene.

Borage.

Caraway.

CORIANDER.

Elecampane.

Fenugreck.

*Horehound.

*Hrssop.

*Lavender.

*Marigold, pot.

MARJORAM, sweet.
RUE.

* Rosemary.

*SAgE.

Savory, summer *SAvory, winter. Skirret.

*ThYMe.

*TANSY.

*Wormwood.

Those marked with $a *$ are perennial, and when once obtained in the garden may be preserved for years, with a little attention. Sow in April, in shallow drills; when up a few inches, thin out to proper distances.

\section{MIXED LAWN-GRASS SEED.}

Particular attention is paid to the selection and mixing of suitable Grasses, for laying down Lawns and Pleasure grounds. Price 30 ets. per quart, or $\$ 6.00$ per bushel.

\section{AGRICULTURAL SEEDS, \&c.}

Selected of the finest quality, and supplied at market rates.

Sweet Vernal Grass. Per. Rye Grass. Orchard Grass. Flax Seed. Red Clover.

White Dutch Clover. Millet.

LUCERNE.

Tпмотну.

Green Grass.

HERD OR RED TOP,

Pear Pips.

BUCKWHEAT.

Blue Grass.

BROOM CORN.

Hungarian Grass. Honey Locust.

Sorgium, or Sugar Cane. Ruta Baga, or Swedish Turnip. OSAGE ORANGE SEED, for Hedges, per $15 . \$ 2.00$.

\section{BIRD SEEDS, \&o.}

Selected of the best quality, free from mustiness and other impurities, so destructive to birds.
Canary.
RAPE.
Bird BASKets.
HEMP.
Mixed Bird Seed.
MaW.
LeTTUCE.
Millet,
Rovgh Rice.
Bath Cups.
Hair for Nests.
Cottle Fish Bone.

\section{TOBACCO SEED.}

Havana, per oz. \$1.00. Pennsylvaria, per oz. 50 cts.

Virginia, “ $50 \mathrm{cts}$. Connecticut Seed Leaf, per oz. 50 c. 


\section{LATAKIA TOBACCO SEED,}

Introduced by the distinguished traveller, Bayar 1 Taylor, from Mount Lebanon. This is considered in the Orient the finest smoking tobacco in the world. It exhales a delicious aromatic odor, resembling that of dried roses, and is believed to be an entirely distinct species, peculiar to Mount Lebanon. Price, per packet, $25 \mathrm{cts}$.

\section{ESCULENT ROOTS AND PLANTS IN SEASON.}

Early Potatoes.

Garlic.

White Onion Sets.

Yeluow Onion Sets.

Cabbage Plants.

Celery "6

EGG
Mushroom Spawn.

Asparagus Roots.

Sweet Potato Slips.

Rhubarb Roots.

LetTuce Plants.

Tomato Plants.

Pepper Plants.

\section{NEW AND DESIRABLE VEGETABLES,}

We take pleasure in offering the following varieties, and can recommend them for their superior qualities.

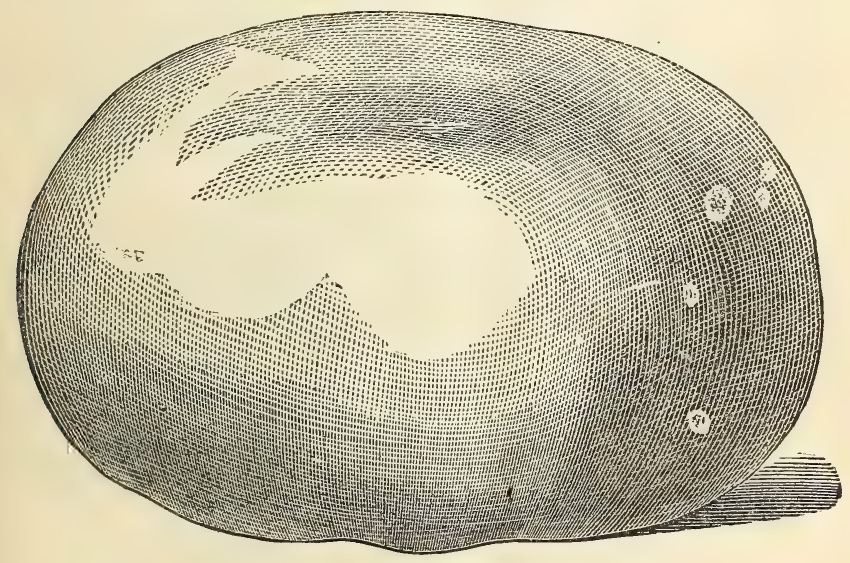

Tilden Tomato.

This valuable variety originated with Mr. Henry Tilden, of Davenport, Iowa. The plant is somewhat dwarf in its habit, the branches rarely reaching three feet in length, even when trained on stakes. It is good, both as an early and late variety, ripening the past season on late ground by the 10th of July, and continued bearing up to the last of October. In shape the largest fruit is uniformly oval, which is the normal form of the variety, the warty excrescences about the calyx, and which so often disfigure the fruit of other varieties, are never seen in the Tilden. The cclor is a brilliant scarlet, and the skin is 
smooth, glossy, and rarely wrinkled, the flesh is remarkably solid and high-flavored, giving a richer, and less watery pulp, when cooked than any other.-Price Per PaCKet, 25 ets.

\section{GIANT WAZ BEAN, (Running.)}

Recently introduced, and differing essentially from the old German Wax Bean, being of a more robust growth, and also more productive, the pods are from six to nine inches in length, and from three-fourths to one inch in breadth, the beans when ripe are of a reddish color. The pods, when fit for use, are of a clear waxy color, perfectly stringless, and when cooked are as tender as marrow, and truly delicious. Cultivation:-Fix strong poles to each hill, which should be three feet apart, and four feet between the rows, enrich with well rotten stable manure, or compost of bone dust and wood ashes, or guano and plaster, well incorporated in the soil; plant four or five beans to a hill, and allow three of the strongest plants to remain. The first planting can be made early in May, and for Fall use make a second planting about the middle of June. They are in their best condition for use, when the pods have attained their full growth, and yellow color. Price per packet, 25 cts.

MIr. Burr, author of the "Vegetables of America," says,- "I have given the Giant Wax Bean a fair trial, and am happy to say, that it has proved every thing you claimed it to be." The American Agriculturist, November, 1866, says,-"Its origin is unknown; but wherever it came from, we welcome it as a valuable addition to our list of varieties."

\section{OLD OOLONY SWEET CORN.}

This variety originated in Plymouth Co., Mass, and is a hybridbetween the Southern white, and the common sweet corn of New England, combining the size of the ear and kernel, and productiveness of the Southern, with the sweetness and tenderness of the Northern parent. For cultivation in the Southern States, it has been found to be peculiarly adapted, as it not only possesses there the sweetness and excellence that distinguish the Sweet Corn of the temperate, and cooler sections, but does not deteriorate by long cultivation, as other sweet varieties almost invariably are found to do. - In packets containing about one ear, -25 ets.

\section{MAUPAY'S STPERIOR TOMATO.}

This tomato has been perfected by the Messrs. Maupay, by crossing the old Bright Scarlet with the Fejee Island rariety.

The fruit is of a beautiful deep red color, in form it is round, slightly flattened, and without a crease or wrinkle. Smoothness of the surface is not only one of its most remarkable, but one of its most desirable characteristics. It is of medium size, and the flesh almost as solid as a beef steak. In proof of their solidity it is not improper to state, that although not of extraordinary size, the average weight is from nine to twelve ounces each. It has very few seeds, and from the solidity of its flesh, comparatively little water. Price por packet, 25 cts. 
CAULIFLOWER, LARGE EARLY ERFURT... Of dwarf growth, head large, close, and compact, one of the best.for cultivation in this country ........................................per packet, 25 cts.

CAULIFLOWER, LE NORMAND... A very superior and certain variety, and a great favorite with market gardeners. Per packet 25 cts.

CELERY, TURNER'S INCOMPARABLE DWARF WHITE...One of the hardiest and best, of a fine nutty flavor. Per packet $25 \mathrm{cts}$.

LETTUCE, FELTON'S INDIA HEAD...An improvement on the old variety, very large and solid....per packet $10 \mathrm{cts.}$, per $0 \mathrm{z} .50 \mathrm{cts}$.

LETTUCE, PERPIGAN.... from Germany, grown for several seasons by our Market Gardeners; large solid heads; stands the heat well. A good summer salad......per packet, 10 cts. per $0 z .50$ ets.

MUSK MELON, PINE APPLE....exquisite fiavor, medium size. A desirable variety...................per packet $10 \mathrm{cts}$. per 0 . $20 \mathrm{cts.}$

MUSK MELON, WHITE JAPAN...Skin, cream white and very thin. flesh thick, remarkably sweet and fine-flavored, ripens early, and is quite productive...............................per pa.ket, 10 cts.

MANGO MELON... a variety of the musk melon used when green for pickling; stuffed and prepared similarly to the large Bell Pepper

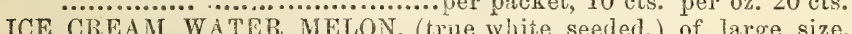
sweet, and excellent flavor...... per packet, $10 \mathrm{cts}$. per oz. $20 \mathrm{cts}$.

PEA, EUGENIE, one of the wrinkled varieties quite popular; of dwarf growth, early and productive..................per qt. 60 ets.

RADISH, EARLY SCARLET, AND WHITE OLIVE-SHAPED, are very early and beautiful varieties, suitable for growing in hotbeds................................................price per oz. 15 cts.

RADISH, SCARLET CHINA, WINTER, a valuable winter Radish, very tender and sweet.............per packet, $10 \mathrm{cts}$. per $0 \mathrm{z} .25 \mathrm{cts}$.

SQUASH, TURBAN, the best variety for fall use.......per pkt. 10 cts.

TOMATO, THE COOK'S FAVORITE...introduced by us, one of the best ; of medium size, smooth and solid color briliiant scarlet. ................................Price per packet, 10 cts. per oz. 50 cts.

TURNIP, TELTOW, OR MARROW...a small yellow variety of delicate flavor..............................................per oz. 20 ct.

The following have been received recently from Europe, and are worth a trial.

BORECOLE, FISHER, HOLMES... extra curled......per packet, $10 \mathrm{cts}$. BROCOLI, OSBORNE'S NEW WHITE WINTER.... per packet, 25 cts. " SNOW'S WHITE WINTER...fine.........per packet, 25 cts.

“ LATE NONPAREIL......................per packet, 25 cts.

CABBAGE, LITTLE PIXIE...a very eœrly dwari variety...............

COBBETT'S EARLY...highly recommended.... per packet, $10 \mathrm{cts}$.

: $\quad$ HEAL'S IMPERIAL, large and solid. per packet, 10 cts. CELERY, DIXON'S NEW MAMMOTH WHITE....per packet, $25 \mathrm{cts}$. CUCUMBER, COOLING'S PROLIFIC......most abundant cropper, of ten producing from three to six fine fruit at a joint length, 18 to 24 inches..................per packet 50 cts. " PIERSON'S LONG GUN...the finest flavored variety grown, length 24 inches...............per packet, 50 cts. 
LETTUCE, NEAPOLITAN...large solid beads.......per packet, 25 cts. PEAS, LITTLE GEM...(M'Lean's,) a wrinkled variety of fine flavor, 1 foot high, requires no sticks.......................per qt. $\$ 1.00$

"ADVANCER, (II'Lean's... new dwarf, blue wrinkled marrow, of fine flavor, the earliest and best of its class, height 2 feet. ..per qt. 60 cts.

“ DIXON'S YORKSHIRE HERO... a new wrinkled variety $2 \frac{1}{2}$ feet high.............................................. per qt. 80 cts. ESSEX RIVAL... a second early variety, $3 \frac{1}{2}$ feet high........... ......................................................per qt. 60 cts. PRINCE OF WALES...the most prolific white wrinkled pea in cultivation, producing pods from near the roots to the top, height four feet........................................per qt. 80 cts.

Of older varieties, especially to be recommended Dreer's Extra Early Pea, still takes the lead among our Gardener's as the earliest, most productive, and even cropper. Our sales are also yearly increasing for Large Early Yorlc Cabbage, and Dreer's White Solid Celery Seed, also our very superior varieties of Caulifiower, imported from the growers in Europe. Especial attention has also been paid to the improvement of our stock of Late Drumhead and Flat Dutch Cabbage Seed, a very important crop with the Farmer and Gardener: we confidently recommend it, as being perfectly pure and reliable, heading up evenly and solid.

\section{GOODRIOH'S SEFDLING POTATOES.}

These highly valuable new seedling potatoes, were raised by the late Rev. Chauncey E. Goodrich, Chaplain of the New York State Lunatic Asylum, at Utica, N. Y. He spent 15 years in experimenting upon the production of new varieties, and raised over sixteen thousand seedlings, of which he esteemed the Harrison and the Early Goodrich (which are twin brothers, and seedlings from the Cuzco,) as the very best.

The Harrison is a white winter variety of high quality and beauty, unequalled in productiveness by any known kind. Mr. Goodrich stated that he had raised at the rate of 600 bushels per acre, when only three years from the seed ball. Price $\$ 5$ per bushel. \$1.50 per peck.

The EARLy Goodrich is the very best and most productive very early potato known. It keeps equally well with the Harrison, and has repeatedly yielded over 350 bushels per acre. Price $\$ 3.50$ per bushel. $\$ 100$ per peck.

Cuzco, large, long, white skin and flesh, deep eyes. Matures about September 15th. Yield very largely, 300 to 400 bushels per acre.Keeps well. Very profitable for market and stock. \$2.50 per bushel

I also offer the White Sprout, a white-skinned and whitefleshed potato, very early and popular in the Pliladelphia market.It is largely grown in New Jersey, and highly esteemed there, as a profitable market variety. $\$ 2.50$ per bushel. 


\section{FLOWER GARDEN.}

Although to the mere economist, flowers are not indispensable or directly remunerative, yet they have become so to the civilized, intelligent and intellectual community in which we live. The most humble cottager, unless deficient in the most simple conceptions of beauty, must have his flower-pot and one or more varieties of flowers. The enthusiastic amateur is no longer content to receive his floricultural novelties at second hand, but must have them direct from the great European centres of Horticulture. We have latterly endeavored to render this necessity of the amateur importing a few seeds or plants unnecessary, by constant attention to obtain every highly recommended novelty, and after testing it, to offer it with our opinion of its merits. We shall continue to do this, and shall endeavor to have, at the earliest day, every valuable acquisition in seeds, bulbs or plants.

Litile pains are taken to have the soil of the flower-beds and borders in a friable and active state, not subject to bake. This is what renders it so difficult for small flower-seeds to survive germination, and for the delicate transplanted annuals to make a start. All that the flowerborder or beds require, is a dry bottom, with an annual supply of prepared compost, made up of barn-yard manure, leaf-mould, or decayed leaves from the woods, and such other refuse as may appear suitable to enrich the heap. With different soils, special applications will be necessary, as stated under the head of Vegetable Garden. The hot-bed frame as there described, will serve for the purpose of the Flower Garden.The only additional requisites are flower-pruning scissors, stakes for tying up plants, labels and flower-pots.

Tre LAwn, which adds so much to the neatness of the Garden, may be extensive or limited in size, but should always be well prepared and neatly kept. Much of the beauty of the lawn is also due to the variety of grass seed sown. The usual practice has been to employ a mixture of several species, which is prepared for sale. Our Lawn grass mixture consists of five varieties, viz.; Sweet Vernal, Green Grass, Blue Grass, Herd Grass and Whito Ciover. From one and $a$ half to two bushels is the quantity generally sown to the acre. Persons who prefer a different mixture, can have it made up to order.

The Flower-beds may be cut out in the lawn, and in these, betding plants from the green-house planted, as soon as the weather becomes suitable; also, choice annuals sown. The following brief lirections will be found reliable. 


\section{Directrons for the Sowing and Hanagement of Flower Seeds.}

Provided the soil is in a proper state, flower seeds may be sown in the open border, in the months of April and May; the best criterion is the state of the soil. The seeds should be sown as soon as the soil becomes dry and friable, after the spring frosts have disappeared. Care should be taken not to sow in a crowded border, as light and air are indispensable. They may also be sown in prepared beds, to be transplanted to the garden. The former is the more simple method, but not always satisfactory, as, during the interval between the sowing of the seed and the period of blooming, the ground occupied is not attractive. The changes of climate, heavy rains and drying winds, with hot sun, render the surface of the soil unfit for the germination of small seed. As to the depth to which seeds should be covered, the best general rule is to cover fine and light seeds very lightly, just enough to protect them from the sun; and in extremely dry weather, a sprinkling of damp moss is very useful. Several varieties are so tender as to require special attention, such as the Calceolaria.

Many annuals are very desirable for the green house, when sown in August. Of these the most important are Sweet Alyssum, Candytuft, Mignonette, Lobelia, Schizanthus, German Stocks, Browallia and several others; these are for winter blooming. Many varieties, as well as the above, may be sown later, for blooming early in spring, such as Pansy, Ageratum, Antirrhinums, China Pink, Dianthus Heddewegii, Laciniatus and Sinensis, Acroclinium Roseum, Linum Grandiflorum, Mimulus, Myosotis, Petunias, Phlox Drummondii, Salpiglossis, Verbena, \&c. For sowing in pots, or seed-pans, the following directions will be found suitable:

The best soil is a mixture of equal parts of sand, leaf-mould and loam, which should be thoroughly mixed; then fill your pots or boxes to within one-half inch of the rim; press the soil firmly and evenly in the pot, which can be done most conveniently with the bottom of an empty flower-pot; then sow your seed evenly over the surface, and, with the addition of a little more sand in the same soil, cover the seeds according to their size, say from one-eighth to one-quarter of an inch, then press the soil as before, even and firm, with the bottom of a flower-pot; water sparingly, enough to keep the soil moist, avoiding either extreme. As soon as the plants appear, they will require your careful attention, as the least over-watering may cause them to "damp off," and suddenly destroy all your hopes. They should now have as much sun as possible, and when the weather is pleasant, some air may be admitted. As soon as the plants are large enough to handle, pick them out of the seed-pot; in other words, transplant them into another pot, placing them akout one inch apart; they must be shaded for a few days from the sun, until they are established. When large enough, they can be planted separately into small pots, and kept thus until the proper season for planting out in the garden.

BIENNIALS.- These do not usually bloom until the second season after sowing. They may be sown out of doors, at least those that are hardy, while a few very desirable ones had better be sown in pots. The following are among the most desirable: Wall-flower, Foxglove, Pinks, Sweet William, Antirrhinum, Hollyhock, Larkspur, Canterbury Bell and others. 
CALCEOLARIA.-As this very desirable flower requires a little special care, the following method should be adopted. The seed should be sown in the latter part of August, or beginning of September, in pots prepared in the following manner: the pot to be half-filled with drainage, over that, the rough sifting of the mould, and the surface covered with soil as fine as possible, half of which should be composed of river sand. When prepared thus, it should be watered with a fine rose, immediately after which sow the seed carefully, without any covering of soil. The pots should then be placed under a close frame or hand-glass, in a shady part of the garden, no artificial heat being required. In large establishments, of course, there are propagating or other houses that will do, where the same kind of moist temperature could be obtained, but any exposure to the sun must be carefully guarded against by mats or paper. If the situation be of the proper temperature, they will require watering but very seldom. As soon as the seedlings are strong enough, they must be picked off in pots prepared as before, and placed in the same situation; from the store pots they will require to be potted off singly: after this the plants will grow very rapidly. Through the winter the plant will thrive well on the shelves near the glass, in the green-house; and, to obtain fine specimens, they must be shifted on freely till the flower-stalks have started, and should always be smoked with tobacco, as soon as the green-fly appears, as no plants in cultivation so readily suffer from this insect as the Calceolaria.

It is necessary to remark, that one of the most frequent causes of the appearance of these injurious insects, is the plant becoming rootbound; to avoid which evil, it is important that it should frequently be re-potted during the growing season.

CINERARIA are more hardy in their growth, and require somewhat less care than the above, but for them the same treatment will suit in sowing of seed, \&c. If required to flower in the winter, seed should be sown in April and May, and in the following months for spring flowering.

CLIMBERS, for garden decoration should be sown in January, February, and March, the earlier the better, as the display for the after season will be in proportion to their early vigor for planting out; such as Cobœa, Thunbergia, Maurandia, Lophospermum, Calampelis (Eccremocarpus,) and Tropæolum of sorts.

CLEMATIS species amongst hardy shrubs, and PENSTEMON, amongst herbaceous plants, are prominent instances of seeds which remain long dormant, often a whole year, before they grow, hence the importance of sowing them as soon as ripe.

Another class often fail to germinate in consequence of the thickness or hardness of the outer skin or integument. We have had seeds of the Erythrina and Canna for months in the ground perfectly dormant, which upon being soaked in hot water for one week have ger. minated finely. 
It shovild be borne in mind, that much of the disappointment that occurs in the sowing of Flower seeds, may be obviated by attention to the foregoing hints.

In the following list we have included all the really desirable novelties, as well as the standard varieties, which have been fully tested in this vicinity.

\section{Flower Seeds by Mail.}

Their portability renders them so easily and cheaply transported by mail, that no one with any pretensions to taste in Floriculture need be without a choice selection. For the accommodation of those who are unacquainted with the varieties, we have put up the following assortments of the most desirable free blooming and showy kinds, which will be promptly mailed (prepaid,) upon the receipt of a remittance.

Correspondénts will please write their names legibly, and in full, with post office, county and state.

No 1. Twenty choice annuals, free bloomers for................\$1.00

"2. Twenty choice biennial and perennial varieties.......... 1.00

“ 3. Ten very choice annual varieties.......................... 1.00

" 4. Ten new and rare varieties................................ 2.00

“ 5. Twenty-five varieties for Green house culture............ 4.00

"6. One hundred varieties annual, biennial and perennial, including many choice sorts, a fine selection.......... 5.00

As an inducement to POSTMASTERS AND OTHERS forming Clubs, we will forward, post-paid, six One Dollar packages for a remittance of F.vo Dollars.

At the se prices, invariably our own selection. The tatest novelties are not includsd in these collections; but a liberal discount will be made from catalogue price when ordering a quantity. 


\section{Novelties and Select List of Flower Seeds.}

\section{WORTHY OF SPECIAL ATTENTION.}

The letters preceding the varieties denote:-b. biennial, or such as last two seasons; $p$. perennial, or such as exist from year to year; $t$. tender, which will not endure the frost; $t . p$. tender perennial, which require the protection of a green-house during the winter; $h$. $h$. half hardy, requiring some protection; $c$. climbers; a * denotes that although the variety may be biennial or perennial, it will bloom the first year, if sown early; the remainder are annuals, which arrive at perfection and die off the first year.

Per Pkt.

ABOBRA VIRIDIFLORA. A beautiful climber, with glossy, dark green foliage, small oval scarlet fruit.............

ABRONIA UMBELLATA. Trailing, clusters of sweet-scented, rosy lilac blossoms, resembling the Verbena...................

p. ACONITUM NAPELLUS. Monk's hood.

ADONIS VERNALIS. (Flos Adonis.) Handsome foliage; flowers crimson. One foot high.

AGERATUM. Valuable plants for large beds or borders, and very useful where cut flowers are in demand; in bloom the whole summer, and succeeding in any soil.

" COELESTINUM NANUM. Dwarf blue......................

" MEXICANUM. Blue. ALBIFLORUM. White. Each........

ALONSOA WARSCEWICZII. Free flowering; bright crimson...

" GRANDIFLORA. Large flowering. Bright Scarlet............ p. AGROSTEMMA CGLI-ROSEA. (Rose of Heaven.) Pink...

ALYSSUII. Free flowering. Pretty little plants, for beds, edgings, or rock work; the annual varieties bloom all summer, also grown in pots for winter flowering.

" BENTHAMII. White. New, large, sweet Alyssum...........

" SWEET. White, very sweet; hardy annual.....................

“ WIERZBECKII. Yellow. Hardy perennial; blooms early.

ANAGALLIS. Dwarf, compact, flowering plants; admirably adapted for ornamental baskets, rock work, etc. The choicest varieties are, GRANDIFLORA EUGENIE, light blue. NAPOLEON III., carmine. Each.....................

ANTIRRHINUM. (Snap Dragon) One of our most showy and useful border plants. The more recently improved varieties of this valuable genus are large, finely shaped flowers of the most brilliant colors, with beautifully marked throats; they succeed in any good garden soil and are very effective in beds. Hardy biennials, blooming the first year from seed; height from 1 to 2 feet....

ANTIRRHINUM MAJUS, TOM THUMB. Very dwa.f, not above 10 inches in height, of compact growth, with bright vermilion-colored flowers.

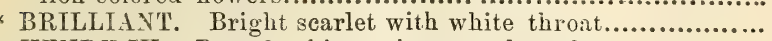

" HENRY IV. Dwarf, white, crimson and scarlet.................

" FIRE-FLY. Orange scarlet, white throat.......................

"DELILA. Carmine, with white throat.

" GALA'THE. Crimson, white throat, large flowering...............

" PAPILIONACEUM. Deep blood scarlet, pure white throat,

"CHOICE MIXED SNAP DRAGON. Finest named varieties

"SNAP DRA';ON. Mixed older varietios. 
p. AQUILEGIA, (Columbine) Fine double varieties, mixed...... " " " single " " "..... ARGEMONE MEXICANA. Yellow poppy-like flowers; hardy... ASTER. (Queen Margaret.) One of the most popular and effective of our garden favorites, producing in profusion flowers in which richness and variety of colors are combined with the most perfect and beautiful form: it is indispensable in every garden or pleasure ground where an autumnal display is desired. T'he French and German Florists have brought this flower to great perfection; we offer all the most choice varieties imported from one of the largest growers in Prussia. All the varieties delight in a rich light soil, and in hot dry weather should be mulched with rotted manure, and well watered.

ASTER. DWARF BOUQUET. A perfect bouquet of flowers...

" TLOBE-FLOWERED PYRAMIDAL. Choice mixed colors..

" COCARDEAU or CROWN. White centres bordered with rich colors............................................................

"NEW VICTORIA. Various colors, flowers as large as the Emperor Aster, habit pyramidal.

"NEW ROSE. Intermediate between the IMBRIQUE and PEONIA ASTERS; robust, with large brilliant flowers.

"NEW EMPEROR. Flowers of great size, very double, and fine form and colors...........................................

"PAONY PERFECTION. Very double, large, and finely shaped, brilliant colors...........................................

“ PAEONIA-FLORA. Choice mixed colors........................

" HEDGEHOG or NEEDLE. A singularly quilled variety of neat habit.....................................................

“ NEW DWARF GLORE FLOWERED IMBRIQUE POMPONE. Extremely pretty, not above twelve inches in height, forming a compact bush, densely set with beautiful, almost globular flowers. All the varieties are very fine brilliant colors

“ NEW LARGE FLOWERED ROBUST DWARF. A valuable improvement on the old dwarf Asters, of robust habit, with handsome foliage, and large beautiful imbricated flowers. In addition, all the varieties are very brilliant in colors, lasting double the time in flower.........................................

" Choice mixed varieties............................................

" German quilled, beautiful colors, mixed................................

“ German mixed colors ..............................................

BALSAM, (Lady Slipper) An old and favorite garden flower, producing its gorgeous masses of beautiful brilliant colored flowers in the greatest profusion; of easy cultivation; succeeds in any good garden soil.

" CAMELLIA-FLOWERED. Very double, and fine colors, mixed, one to two feet high........................................

" NEW ROSE-FLOWERED. Superb double flowers...............

" Mixed Balsams, or Lady Slipper.................................. Balloon Vine (Cardiospermum.) Rapid growing climber............ Bartonia Aurea. Golden-flowered. 


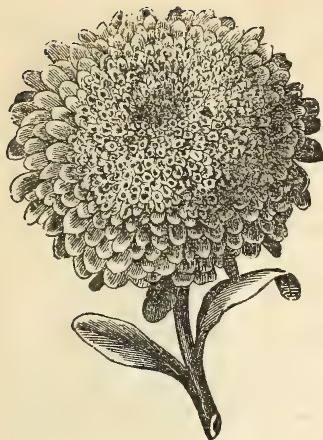

$\frac{1}{2}$ natural size.

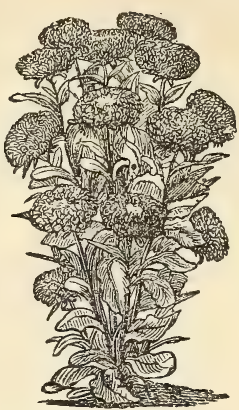

10 natural size

DWARF BOUQUET ASTERS.

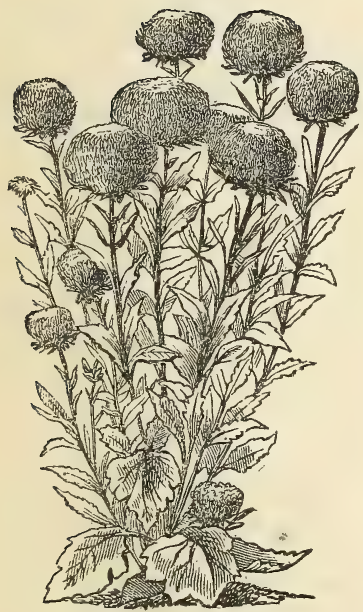

P军ONIA ASTER.

$\frac{1}{10}$ natural size.

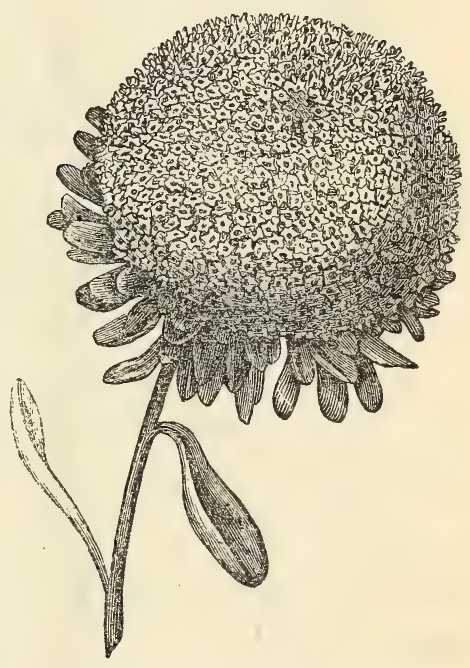

QUILLED ASTERS.

$\frac{1}{2}$ natural size. 
Bidens Atrosangurnea. Dark red; beautiful......................

BRACHYCOME IBERIDIFOLIA. (Swan River Daisy.) Free flowering dwarf-growing plant, corered during the greater part of the summer with a profusion of pretty Cineraria-like flowers of a light blue color.

"ALBIFLORA. A white variety of the above.

BROWAIIIA. Very handsome profuse blooming plants, covered with rich strikingly beautiful flowers during the summer and autumn months; blooms finely in the winter, if sown in August.

" ELATA CORULEA. Sky blue. ALBA. Pure white.

" GRANDIFLORA. Large sky blue.................................

BRYONOPSIS FRYTHROCARPA. Splendid climber, with beautiful scarlet fruit, marbled white.....................

CACAIIA, (Tassel. Flower) A neat annual of easy culture, with tassel-shaped flowers, blooms from July to September; $1 \frac{1}{2}$ feet.

"ACREA. Golden yellow.

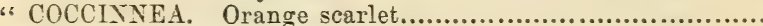

Calandrina elegans; grandiflora, each.................................

CALENDLLA PONGEI, FL. PL. Double white, hybrid marigold.

CALIIRHOF PEDATA, (Nuttalia) Rich violet or purple crimson, close petaled flowers, with white centre.............

" TERTICILLATA. An extremely floriferous creeper, flowers of the same color, but double the size of $C$. pedata.............

“ PEDATA NANA. A superb dwarf variety

10

10

25

CALIIOPSIS, or COREOPSIS. Showy, free-flowering and heautiful hardy annuals: the tall varieties are very effective in mixed borders, while the dwarf kinds, from their close, compact habit of growth, make fine bedding plants : of easy cultivation.

"ATKINSONII. Yellow and crimson; 3 feet.

"BICOLOR, (Tinctoria) Yellow, crimson centre: 3 feet........

"CARDAMINEFOLIA HYBRIDA. Brilliant rellow; growth pyramidal: compact and free flowering; $1 \frac{1}{2}$ feet...............

" DRUMMONDII. Large yellow flowers; 1 foot.................

" MARMORATA. Crimson brown, marbled with yellow; 2 feet.

“ NIGRA SPECIOSA. Rich velvety crimson: 2 feet............

CALCEOLARIA, See list of greenhouse seeds.

CAMPANUIA PYRAMIDAIIS. Blue, beautiful and stately perennial.............................................

" SPECULUM, ( Tenus' looking glass) Rich blue...................

" ATTICA. Dwarf, light blue, large flowers.....................

CANARY BIRD FIOWFR. (Tropæolum Peregrinum.) With yellow canary-like flowers; an ornamental climber.

CANDYTUF'T, (Iberis) Beautiful and effective hardy anuuals, for growing in beds, or masses; the white rarieties are much grown by florists for bouquets.

" ROCKET. White. UMBELLATA. Purple. Each. ..........

" CRIMSON. Dark red. CPOWN FLOWERED. White...... 
p. CANTERBURY BELL. (Campanula Media) When well grown, are among the most attractive of border plants; they succeed in light rich soil, planted about 2 feet apart. Hardy.

" SINGLE BLUE. SINGLE WHITE. Each....................

“ DOUBLE BLUE. DOUBLE WHITE. Each....................

CARINATION. (Dianthus Caryophyllus.) The Carnation Pinks are general favorites for their delicious fragrance and richness of colors. The seed we offer has been imported from the best sources, in Europe, and will produce splendid double flowers.

" FINEST GERMAN, (imported,) in packages of 50 seeds......

" " FRENCH,

“ REMONTANT, or PERPETUAL,

$66 \quad 66$

" FINE DOUBLE, mixed.

CATCHFLY. (Silene Armeria) Hardy, free blooming annuals.

“ LOBEL'S RED. LOBEL'S WHITE. Mixed....................

“ PSEUDO-ATOCION. Rosy pink with white centre............

CELOSIA SPICATA ROSEA. Feathery spikes of bright rose

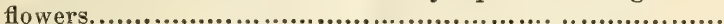

“ PYRAMIDALIS AUREA. Golden spikes.......................

CENTAUREA AMERICANA. Lilac purple, large and showy....

CENTRANTHUS MACROSIPHON. Pretty, compact growing plant, with long-tubed red flowers, grows freely..............

". ALBUS. White................................................

CHRYSANTHEMUM. Showy and effective summer flowering border plants, quite distinct from $C$ Indica, the hardy perennial autumn flowering varieties. The varieties are:

"BURRIDGEANUM. Crimson. ALBUM. Double white Each.

" TRICOLOR. Yellow and white. GOLDEN YELLOW. "

" VENUSTUM. White, with crimson centre, extra fine........

" CORONARIUM. Dwarf, yellow..................................

CHLORA GRANDIFIORA. Beautiful gentiane», about 15 inches high, with handsome glossy leaves, large golden yellow flowers, grows vigorously in the open borders.........

CINERARIA. See list of greenhouse seeds.

CLARKIA. An old and favorite bardy annual, growing and producing freely; is a cheerful-looking flower. A native of the Rocky mountains.

“ ELEGANS. Rosy purple. PULCHELLA. Deep rose. Each.

“ PULCHERRIMA. Deep Magenta. DOUBLE. Each............

p. CLEMATIS FLAMMULA. Hardy climber, flowers white and fragrant

CLFOME GRANDIFLORA. Spider Plant. Rose-colored flowers.

CLINTONIA ELEGANS. Pale blue, pretty dwarf plant............

“ PULCHELLA. Bright blue, yellow centre......................

COBCEA SCANDENS. Rapid climber, large bell-shaped blue flowers. In sowing, place the seeds edgewise and cover with light soil. Comes up best in a hot-bed............

COCKSCOMB. (Celosia Cristala.) Crnamental, curiouslooking flowers; well known favorites.

“DWARF CRIMSON. Large, velvet-like combs, (extra)......

“ YELLOW, CRIMSON, and mixed; each.......................... 
COCCINIA INDICA. Splendid climber, with beautiful smooth, glossy, pentagonal leares, about 4 inches long by 3 inches broad, contrasting beautifully with the fine, snowwhite, bell-shaped flower, fruit brilliant carmine, growth vigorous, habit handsome.

COLLINSIA BICOLOR. Purple and white, free blooming, pretty.

"MARMORATA. Lilac and white, marbled.

COMMELINA CELESTIS. A tuberous-rooted plant, with rich blue flowers, free blooming and very pretty

CONVOIVUIUS MAJOR,' (Morning Glory.) One of the handsomest annuals in cultivation; the beauty and delicacy of their colors are unsurpassed. A rapid climber. Fine mixed varieties .......................................................

" Large Blue... ........................................................

" Burridgii rosy crimson, with white centre.........................

CONVOLVULUS MINOR, or Tricolor, free flowering; dwarf, showy plants, producing, in beds and mixed borders, an unusually brilliant effect.

“ SPLENDENS. Violet, with white centre........................

“ WHITE, STRIPED, AND BLUE, each.........................

" (Tricolor, ) fl. pl. double.............................................

“ AUREUS SUPERBUS. New, golden yellow flowers............

" CANTABRICUS, rosy purple, beautiful trailer, for hanging baskets, or for bedding plant.

" MAURITANICUS, beautiful for hanging baskets and vases...

CREPIS BARBATUS. Golden Hawkweed............................

CYPRESS VINE, (Ipomæa quamoclit) A very beautiful climber, with delicate fern-like foliage, and masses of bright erimson flowers. Plant about the 10th of May.................

" WHITE. A pure white variety of the above, true................

CYANUS, (Blue Bottle.) Mixed.........................................

p. DAISY, (Bellis perennis.) Finest double imported.................

t. $p$. * DAHLIA. Saved from fine double varieties.....................

DATURA. An ornamental class of plants, very showy. In large clumps and borders of shrubbery they produce an excellent effect, the following are the most desirable.

"ATROVIOLACEA PLENISSIMA, from Cochin China, $4 \frac{1}{2}$ feet high, flowers dark violet.........................................

" FASTUOSA HUBERIANA. Superb variety, 5 feet in beight, with large double lilac flowers, inner parts almost pure white, valuable annual for groups.

"HUMULIS. A rare and ornamental plant, with large, conspicuous, double-drooping flowers, trumpet-shaped, of a rich Nankeen yellow; delightfully fragrant.............................

“WRIGHTII, (Meteloides.) White, bordered with blue...........

DELPHINIUM FORMOSUM. Spleedid hardy perennial Larkspur, brilliant hlue flowers; flow ər's the first year, if planted early .....................................................

" MONS. MEUNER. Fine large blue...............................

“CHINENSE PUMILUM. Azure blue, dwarf, free-flowering. 
DIANTHUS, (Pinks) A magnificent genus, embracing some of the most popular flowers in cultivation, of great variety of color and profusion of bloom. Hardy biennials, blooming the first season from seed.

" CHINENSIS, (Chinaor Indian Pink) Superb double varieties.

" CHINENSIS CORONATUS. A beautiful hybrid, large flowers of fine form and great substance, pure white, with broad stripes of various shades of brilliant purplish orimson

" IMPERIALIS. Very fine, double...............................

“ FLORA PLENA ALBA. Double white, Indian pink...........

" NANUS, VAR. $\triangle$ TRO-SANGUINEUS PL. A fine aequisition; the plant is five inches high, flowers globular and profuse; color, dark blood-red.....................................

"HEDDEWIGI. (New Japan Pink) Colors vary from the richest velvety crimson, to the most delicate rose; flowers from 2 to 4 inches in diameter, very showy.

" HEDDEWIGI, FL. PL. A fine double variety of the original type, beautiful colors.............................................

" LACINIATUS. Remarkably large blossoms of superb colors, with fringed edges.................................................

" LACINIATUS, FL. PL. A double variety.......................

"ATRO-PURPUREUS, FL. PL. Double blood-red hybrid.

"ATRO-COCCINEUS. A brilliant scarlet, very showy variety.

h.b. DIGITALIS. (Foxglove) Handsome and highly ornamental plant. of stately growth and varied colors. The varieties are PURPLE, WHITE, YELLOW, and MIXED..............

ECCREMOCARPUS SCABER. Rapid growth, orange flowers, a beautiful climber........................................

FCHIUM CRETICUM. Most beautiful, with brilliant scarlet flowers; remarkably effective bedding plant.........

EGG PLANT, SCARLET CHINESE. Very ornamental............

ERYSIMUM PEROFFSKIANUM. From Palestine, orange flowers

ERYTHRAEA RAMOSISSIMA. Fine rose-flowered Gentianes, forming dwarf compact bushes, suitable for edges and dwarf beds..............................................

ESCHSCHOITZIA. (California Poppy) A profuse flowering and attractive hardy annual for beds or masses.

" CALIFORNICA, yellow CROCEA, orange, ALBA white, each

EUTOCA ORTGIESIANA. A new species, nearly creeping in its habit, introduced from Mexico, flowers, light and dark lilac.

GAILLARDIA. Splendid bedding plants, remarkable for the profusion and brilliancy of their flowers, continuing in beauty during summer and autumn.

" ALBA MARGINATA. White edged. ARISTATA. Yellow.

“ PICTA. Red and orange. MIXED. Each........................

" RICHARDSONII. Orange, with brown centre......................

GAURA LINDHEIMERA. Spikes of white and red tinted blossoms, free-flowering, hardy perennial...........................

GILIA. Very pretty dwarf plants, early and free blonmers, valuable for massing.

"ALBA. Pure white. CAPITATA MAJOR. Sky blue.

“ TRICOLOR. White, lilac, and purple, each....................... 
GIADIOLUS, FINE HYBRID. Sared from first class rarieties; special directions furnished for their cultivation........

GODETIA, THE BRIDE. Pure white, with crimson belt.

"ROSEA-ALBA, TOI THUMB. Flower pure white, with a brilliant rose blotch at the base of each petal.................

" RUBICUNDA SPLENDENS.

c. GOURD, ORIAMENTAL, (Cucurbita) A most interesting genus, with striking foliage and most singular fruit.

. BOTTLE OR CALABASH..... .....................................

" CLUB-SHAPED. 4 to 5 feet long.................................

، EGG-SHAPED. MOCK ORANGE.............................

" POWDER HORN..................................................

" SMALL GOOSEBERRY

GYPSOPHILLA MURALIS. Pink, suitable for hanging baskets.

" PANICULATA. A hardy perennjal; flowers are beautiful for bouquets, imparting a light airy appearance................

"SAXIFRAGA. A lovely miniature species, with delicate branches covered with white flowers, for edgings and dwarf beds; very pretty.

HEARTSEASE. See Pansy.

HELIANTHUS. (Sun Flower) CaLifornian. Fine double yellow " NANA. Dwarf Sun Flower...

.

.

PALUSTRIS. Large showy pink flowers, a hardy perennial......

HOLLYHOCK. (Althea Rosea) This splendid plant, now with the Dahlia for summer decorations, and from its stately growth and the varied colors of its magnificent spikes of Howers, may justly claim a place in every large garden or pleasure ground: a hardy perennial.

، SUPERB ENGLISH VARIETIES, mixed....................... " " " " assortments of eight beau-

tiful colors, each separate.....................................

c.p. HONEYSUCKLE, Chinese, erergreen..........................

c. HXACINTH BEAN, (Dotichos) rapid growing, free-flowering climbers for corering arbors, trellises, etc., with lilac-blue flowers, an:l seed pods of a deep purple maroon color........

"ALBA. A white variety of the above............................

IBERIS LINIFOLIA. A fine autumn-flowered annual species, with delicate rose-colored umbels.......................

ICE PLANT. (See Mesembryanthemum.)

IPOMOEA. (Horning Glory,) of rapid growth and beautiful flowers. For covering old walls, trellises, arbors, or stumps of trees, they are invaluable.

"COCCINNEA. Scarlet, sold as the Star "Ipomce.".............

" LIMBATA. Violet, margined with white, fine..................

"STRIATA NOVA. Beautiful striped, three-colored............

“. RUBRA COERULEA. Sky blue, large..........................

IPOMOPSIS ELEGANS. Produces long spikes of scarlet flowers, a half-hardy biennial........................................

" ROSEA, CUPREATA, JAUNE CANARIE. Three new. varieties of this favorite ornamental plant.................... 
IANTANA. A remarkably handsome free-flowering genus of plants, with brilliantly colored flowers, very effective either for pot culture or for bedding purposes. Seed saved from all the finest named varieties, tender perennial.

LARKSPUR, (Delphinium.) Plants possessing almost every requisite for the adornment of the garden or parterre. Profuse bloomers. They all succeed best, if sown in the autumn, or very early in the spring.

" DWARF ROCKET, GERMAN. Finest mixed, double.

" HYACINTH-FLOWERED. Extra double, finest mixed variety

"BRANCHING, or STOCK-FLOWERED. Double, finest mixed, great variety of colors.........................................

" TRI-COLOR. Three-colored branching.........................

c. LATHYRUS LATIFOLIUS. Everlasting Pea, showy, freeflowering, hardy perennial plant, growing in any common soil, very ornamental on trellis work, old stumps, or for covering fences or walls......................................

. LEPTOSIPHON HYBRIDUS. New miniature variety of various shades and colors.............................................

p. LILIUM GIGANTEUM. A noble plant of stately growth, with dark green heart-shaped leaves, and large trumpetshaped white, flower.............................................

$p$ " TENUIFOLIUM, new and pretty.............................

LIMNANTHES DOUGLASSII. RosEA, rose-colored...............

LINARIA CYMBALLARIA, KENILWORTH IVY, suitable for hanging baskets...........................................

LINUM GRANDIFLORUM COCCINEUM. (Superb scarlet flax,) one of the most effective and showy annuals we have...................................................

" LEWISII, blue, with white stripes.............................

c. LOASA LATERITIA. With curious orange-red flowers......

IOBEIA ERINUS SPECIOSA. Compact growth, fine for vases. This variety blooms during the entire summer in the open borders; flowers of a superb ultramarine blue......

" ERINUS COMPACTA ALBA. Fine, pure white...............

"6 " " Dark blue...............................

" " PAXTONIANA. Compact growth, fine................

" RAMOSA. Purple blue, with white eye..........................

c. LOPHOSPERMUM SCANDENS. Ornamental climber, with showy, fox-glove-like flowers, of a bright rose-color..........

“ HENDERSONII. Similar to the above, with darker flowers. LOTUS JACOB ÆUS. Dark brown flowers, fine for pot culture. IUPINUS HAR'TWEII CELESTINUS. Light blue, shaded with rose..................................................

“VENUSTUS TPI-COLOR. A very pretty new Lupin, with handsome deep green foliage, flowers purple, white and blue, height two feet..........................................

“ DUNNETTI ATROVIOLACEUS. Flowers dark violet........

" ALBA COCCINEUS. White and red, heautiful..................

" CliUiKSHANKII. Variegated............................. 
IUPINUS CHOICE MIXED ANNUAL VARIETIES........ " " " PERENNIAL " .....................

JYCHNIS HYBRIDA HAAGEANA. Very beautiful, large brilliant orange-scarlet, and light and dark crimson, whiteflaked flowers, dwarf and free-flowering......

p. " CHALCEDONICA. Scarlet perennial...............................

p. " " ALBA. White. ROSEA. Rose...........................

MARIGOLD, (Tagetes) Large African, yellow and orange...

“ DWARF FRENCH. Fine rich colors, very double...............

“ PIGMY DWARF. Very dwarf. Miniature variety.............

“ RANUNCULUS, (Calendula) English Marigold...................

MARTYNIA FRAGRANS. Large fragrant flowers..................

MARVEL OF PERU. (Mirabilis) A well- known and favorite flower, conmonly known as the Four O'clock, fine mixed varieties and colors

MAURANDIA, species. A beautiful tribe of slendergrowing rapid climbers, blooming profusely until quite late in the autumn. The varieties are,-

"ALBIFLORA. Pure white.

“ BARCLAYANA. Purple, free bloomer............................

“ ROSEA. Dark rose...............................................

IMEOTHRIA PENDULA. Pretty hardy climber, with handsome foliage, and small fruit, black on coming to maturity, fine for trellises..........................................

MESEMBRYANTHEMUM CRYSTALLINUM. Ice plant........

" TRICOLOR. Rose pink, with purple centre......................

“ GLABRUM. (Dew Plant) light yellow.............................

MIGNONETTF, (Reseda Odorata) A well-known favorite.

" NEW LARGE-FLOWERED. Best for pot culture..............

MIMULUS, OR MONKEY-FLOWER. Showy flowers, suitable for the green-house or moist shady situations in the garden.

" MOSCHATUS. Musk Plant; fine in hanging-baskets.........

"QUINQUEVULNERUS, MAXIMUS. Very large and finely spotted varieties, showy and effective.

" HYBRIDUS TIGRINUS. A really charming and valuable acquisition, beautifully tigered or spotted as the Tigered Catceolarias, and Tydeas..........................................

MUKIA SCABRELIA. Pretty climber, with lobed heartshaped leaves, small scarlet berries, hardy.

MYOSOTIS, on FORGET-ME-NOT. Neat and beautiful. little plants; succeeds best in a shady situation. The varieties are,-Alpestris, Alpine; Azorica, Azorean; Palustris, true, forget-me-not; Alpestris, Alba, white, each...

NASTURTIUM, (Tropæolum) The varieties are all desirable, either for the flower border, for pots, or green-house culture. The following are the most ehoice:

" TOM TIIUMB. Very dwarf, scarlet and yellow, each..........

" " " " PEARL, cream color............................

" " " 6 BEAUTY, orange-spotted.......................

“ KING OF THE TOM THUMBS. Bluish green in foliage, intense scarlet flowers, the best variety in habit, aud the brightest in color.......................................... 
NASTURTIUM, KING THEODORE. Selected from King of Tom Thumb, having the same bluish-green foliage, with intense black flowers.........................................

“ CARTER'S CRYSTAL PALACE GEM. Dwarf, sulphur-col. flowers, dark red spot near the base of each petal.............

“ LARGE DARK CRIMSON. Very showy ........................

“ CATTELL'S DWARF CRIMSON, and SCARLET, each......... NEMOPHILA, (Grove Love.) Of neat compact uniform habit of growth, comprising varied and be๕utiful colors, bloom freely all summer. The varieties are,-Insignis, blue: Maculata, white with lilac vein, each....................

"MARGINATA. Azure blue, edged with white.................. NIGELLA DAMASCENA, (Love in a Mist.) Blue flowers,....... " " NANA. A dwarf variety. " .......

p. E NOTHERA GRANDIFLORA. Evening primrose, yellow, ......

" ROSEA, a new dwarf rose-flowering annual,....................

“ BISTORTA VEITCHIANA. Neat dark yellow,................

“ DRUMMONDII NANA. A golden yellow blossom,..............

OXALIS ROSEA. Dwarf, with clusters of rose-colored blossoms

" FLORIBUNDA ROSEA. New, very fine free-flowering.......

PALAFOXIA TEXANA. Pretty fragrant, brown and red flowers,

PHACELIA CONGESTA. Pretty blue annual.......................

PHLOX DRUMMONDII. An indispensable plant for bedding, quite as desirable as Verbena. The following are choice.

" ALBA. Pure white.................................................

" OCCULTA. White, with dark eye.................................

“ LOUIS NAPOLEON. Brilliant scarlet............................

“ LEOPOLDIANA. Pink..........................................

“ RADOWITZI. Dark rose, striped with white....................

“ MARMORATA. Marbled.........................................

“ BLACK WARRIOR. Very dark..................................

“ QUEEN VICTORIA. Violet with white eye......................

“ EMPRESS EUGENIE. Rose....................................

" VIOLACEA: Violet...................................................

“ ISABEL. Light yellow............................................

" CHOICE MIXED. Finest varieties..............................

“ GOOD MIXED. Old varieties....................................

“ PERENNIAL VARIETIES. Mixed..............................

PINKS. (Dianthus) EXTRA DOUBLE CHINA. Picturesque colors, fine, hardy biennial..

" Fine Garden Double and fine perennia......................

“ PICOTEE. Finest selected English perennial......................

“ PHEASANT'S EYE. (Dianthus Phemarius) Perennial......

"PLUMARIUS NANUS. A new dwarf, double white variety, producing all double flowering plants from seed, very compact, not above six inches in height. Perennial................

PANSY, (Viola.Tricolor) An indispensable and charming hardy perennial. The best blooms are from seed sown in the Autumn, and slightly protected in frames during the Winter. These flower early in the Spring. The plants from Spring sowing should be planted out in a shady border, and will produce fine blooms in the Fall. They require a fresh soil, well enriched with decomposed manure. 


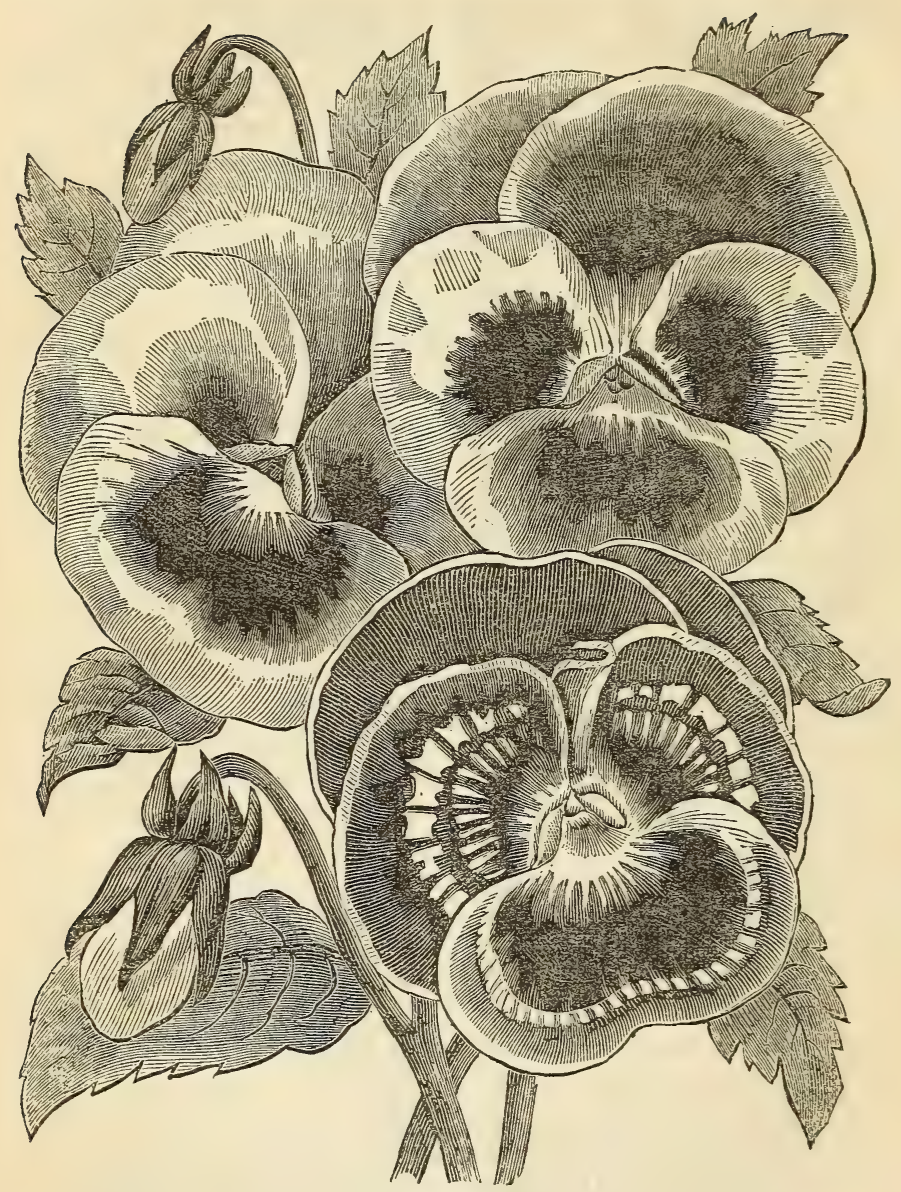

PANSY, DREER'S PREMIUM VARIETIES. Saved from first class flowers, with special directions how to cultivate.. to " best English Imported....................................... 2:

" new light blue.......................................................... 2\%

“ ROI DES NOIRS, new blaek......................................... 25

" PURPLE. White-edged .........................................

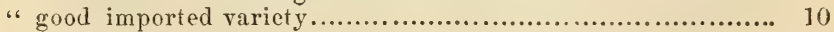

PENSTEMON. Choice mixed varieties, ........................ 10 
PETUNIA. For out-door decoration, there is scarcely a plant equal to this. It commences to bloom early and continues a mass of bloom the whole season. Of late years, the striped and blotched varieties have been much improved.

“ SPLENDID HYBRID VARIETIES. Mixed, very choice,......

“ BUCHANAN'S NEW BLOTCHED. Beautifully spotted,........

“ DOUBLE HYDRIDIZED (very uncertain from seed),............

“ COUNTESS OF ELLESMERE, dark rose, white throat........

“ CERMESINA GRANDIFLORA, with white throat,...............

" PURPLE AND WHITE, mixed, or separate, each.

PORTUIACA. Plants of easy culture, luxuriating in an exposed sunny situation; flowers large and of many rich shades of color, and producel throughout the summer in the greatest profusion. The varieties are,-

" ALBA, white; CARYOPHYLLOIDES. Carnation striped,....

" AURANTIACA. Orange. SPLENDENS. Crimson purple,

"THORBURNII. Yellow. THELLUSONII. Scarlet,...........

' ROSEA. Rose-colored. Mixed................................

" GRANDIFLORA FLO. PL. NEW DOUBLE..................

POIYANTHUS. Finest English varieties, hardy per......... $66 \quad 66$

POPPY, (Papaver) Showy and easily cultivated flowers. Sow early in the spring; will not bear transplanting. The varieties are,-CARNATION, PAONIA-FLORA, DOUBLE WHITE, RANUNCULUS, OPIUM. Fine, mixed varieties, each

PRIMULA VERIS. English cowslip, perennial.....................

SALPIGLOSSIS. Neat and beautiful plants, suitable for potculture or the flower-border, blooming all summer. The varieties are,-PICTA, beautifully veined; COCCINNEA, scarlet; LUTEA, yellow. Also fine mixed varieties, each,

SANVITALIA. PROCUMBENS FLO. PLENO. This new double-flowered variety is far larger in flower than in the single-flowered species: the color is a uniform bright golden-yellow, a valuable bedding plant,..........................

SAPONARIA. Of dwarf compact growth, profusion of bloom throughout summer and late autumn. The varieties are,Multiflora, rosy pink; OCrmoidies, a perennial variety, one of the finest plants for covering rock work each,.........

"CALABRICA MARGINATA. Color rose and white..............

SCARLET RUNNER. (Phaseolus Coccineus) Flowering Bean....

SCABIOSA (Mourning Bride, or Sweet Scabius). Plants with beautiful flowers; adapted for border cultivation, hardy.

" Fine German varieties ; mixed.......................................

‘ Stellata (Starry Mourning Bride)......................................

" NANA. Dwarf. CANDIDISSIMA. White, each.................

SCHIZANTHUS. A splendid class of plants, combining elegance of growth, with a rich profusion of flowers, valuable for green-house decorations, for which purpose sow in August. The varieties are,-Homiss, blue, lilac, white and yellow; Grahamir, red and orange; Grandiflorus Occulatus, various; Pinvatus, purple, white and yellow; Priestri, white, lilac and primrose, each. 
SEDUU. Useful and pretty little plants, growing freely on rockwork, rustic-work, hanging-baskets, \&c. Mixed....

SENECIO OR JACOBCEA. Free growing plants, producing their gay-colored flowers in great profusion. The varieties are,-Dwarf Double Purple, Dwarf Double White, Dwarf Double Carmine, Fine Double Mlxed.

SENSITIVE PLANT. (Mimosa Pudica).

10

SILENE RETICULATA. Brilliant red; very profuse blooming; extremely showy species, two feet in height......

SOLANUM CAPSICASTRUM. A dwarf variety, with red, cherry-like fruit, quite ornamental in pots in the green-house.

STOCKS, (Mathiola) The Stock Gilly flower is one of the most popular, beautiful and important of our garden favorites; and whether for bedding, massing, or pot culture, it is unsurpassed either for brilliancy and diversity of color, or for profusion and duration of bloom. The TEN WEEK STOCK, (Mathiola annua,) is most generally cultivated, and blooms 10 to 12 weeks after being sown; they grow from 6 to 15 inches high, and when grown in rich soil, and occasionally watered with weak guano water, throw out an immense quantity of lateral spikes of bloom, so that each plant forms a perfect bouquet of delightful fragrance. We offer the following select varieties, imported from one of the best growers in Prussia :-

STOCKS, LARGE FLOWERED TENWEEK. Mixed.........

66

66

66

ae

66

66

66

66

66

16

66

66

36

66

66

\$6

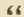

66

66

66

66

66

66

66

66

DWARE TENWEEK. NeW aurora color............

NEW CANARY .................

CRIMSON ..................., 10

BLUE.......................... 10

PURPLE ...................... 10

WHITE $\ldots \ldots \ldots \ldots \ldots \ldots \ldots \ldots . . . \ldots$

NEW SNOW WHITE........ 20

DARK CRIMSON............. 20

SCARLET.................... 10

DWARF BOUQUET. CRIMSON and Rose, each...... 20

VICTORIA SCARLET. Very beautiful............... 20

INTER MLDIATE SCARLET. Very beautiful...... 10

، WHITE ............................. 10

AUTUMNAL, OR INTERMEDIATE. Choice mixed 10

b. PERPETUAL EMPEROR. Choice colors mixed.. 10

b. BROMPTON OR WINTER. Choice colors mixed 10

SWEET WILLIAM, (Dianthus barbatus) A well known free-flowering perennial, producing a splendid effect in beds, mixed flower and shrubbery borders.

“ HUNT'S MAGNIFICENT AURICULA-FLOWERED ...........

، DEAN'S AURICULA-EYED .......................................

" NEW DARK. Very rich, dark colors...............................

“ CHOICE DOUBLE.......................................................

“ MIXED. Good varieties................................................. 
SWEFT PEAS, (Lathyrus). Very beautiful, fragrant and free-flowering climbing piants, flowering all summer.

" SIX COLORS. Separate or mixed, each.

" BROWN'S INVINCIBLE SCARLET. A new intense scarlet variety of the sweet pea, very beautiful........................

TAGETES SIGINAA PUMICA, (VILMORIN.) This is really an acquisition to our list of annuals-its dwarf habit, compact and bushy growth, with its densely covered, bright yellow flowers, must give it a prominent position, and prove valuable as well for borders as for beds, planted either by itself, or alternated with different colors.............

THUNBERGIA, desirable climbing plants, constant bloomers; the most desirable are Alata, buff dark eye; AuranTICA, orange dark eye ; BAKERII, pure white, each............

"ÁLL COLORS. Mixed.

TOURNEFORTIA. Summer Heliotrope.............................. TROPAOLUM. See Nasturtium.

VALERIANA. Red and white, perennial, each......................

VERBASCUM PHCENICIA. Hardy perennial........................

VERBENA HYBRIDA. Seed saved from the finest named

varieties ........................................................

" choice mixed.........................................................

" AUBLETIA. Reddish purple, hardy perennial..................

VERONICA SYRIACA. Bright blue and white... .................

VINCA ROSEA and ALBA. Ornamental and free bloomingfine for bedding out in summer-known as the Madagascar Periwinkle, each.............................................

"ROSEA NOV. SPEC. Pure white, without disk, constant variety .......................................................

VIRGINIAN STOCK. (Malcomia) Red and white, each.............

VISCARIA OCULATA. Pink, with rich crimson eye................ " NANA. Dwarf, bright rose.............................

VIOLET. (Viola Odorata) Single, sweet violet........................ WALL-FLOWER. Fine German, mixed...................... Blood-colored......................................

WHITIAVIA GRANDIFIORA. Fine violet-blue, one foot high, very effective for bedding........................... 5

" ALBA. A white variety of the above..............................

ZINNIA ELEGANS, FL., PL., DOUBLF ZINNIA. This proves to be quite an acquisition to our list of annuals. Its splendid double flowers rivalling in beanty, size and form moderate-sized Dahlias. Seed, saved from the best double flowers, per paper.......................................

"New double, in packets, eight select colors, each separate...... 1.00

" DOUBLE. Saved from good flowers............................... 10

"SINGLE. Scarlet white, yellow, and eight colors mixed, each 5 


\section{EVERLASTING FLOWERS.}

These are desirable for making up Winter Bouquets and Wreaths. They should be cut when in perfection, and dried slowly in the shade.

ACROCIINIUM. Charming everlasting flowers, valuable for winter bouquets, flowering freely in any good garden soilone foot high

" ROSEUM. Bright rose. ALBUM. Pure white, each........... AMMOBIUM ALATUM. White, hardy, two feet..................... GOMPHRENA (Globe amaranthus) Handsome everlastings, with showy flowers, suitable for winter bouquets, familiarly known as the "Bachelor's Button."

" ALBA. White. PURPUREA, rich crimson, each................

" AUREA. Orange. STRIATA. Striped " ..................

HELICHRYSUM. Exceedingly éfrective in mixed flower borders; the flowers, if cut when young, are valuable for winter bouquets; succeed in any rich soil.

" MACRANTHUM. Large pink flowers, two feet................

" NANUM ATRO-SANGUINEUM. Brilliant deep crimson......

" ALBUM. Double white, pure,...................................

" LUCIDUM. Double yellow. " ".............................

" MONSTROSUM. Large showy flowers, variety of colors.......

" COMPOSITUM MAXIMUM. Double, all colors mixed.......

" Fine Mixed Varieties, assorted colors............................

HELIPTERUM SANFORDII. A very pretty and distinct annual of a dwarf tufted habit, growing on ordinary soil, about nine inches high, with neat foliage, and large globular clusters of bright golden yellow flowers.

MICROPUS SUPINUS. Hardy, of dwarf compact growth, bright yellow flowers, very handsome for the open borders.

POLYCOLYMNA STUARTII. White, hardy......................

RHODANTHE. A beautiful class of Everlastings for winter bouquets. The flowers require to be gathered when young, and dried in the shade. Valuable for pot or border culture.

" ATRO-SANGUINEA. Dwarf, branching habit, disk of dark violet or crimson brown shade, ray scales of a bright purple or Magenta color..............................................

" MACULATA. Bright rosy purple, yellow disk..................

" " " ALBA. Silvery white....................................

" MANGLESII. Bright rose, silvery calyx.......................

h. h. $p$. STATIEE BONDUELLI. Deep golden yellow................

66 6. SINUATA. Purple and yellow...................

WAITZIA AUREA. A handsome half hardy annual eighteen inches in height, branched at the base, bearing clusters of bright yellow flowers, one inch in diameter.................

" CORYMBOSA. Clusters of elegant flowers, about one inch across, of a deep amaranth on the outer part, paler inside, and with yellow disk; succeeds well in light soil.........

XERANTHEMUM. Remarkably showy and free, flowering, hardy annual. The varieties are,-DOUBLE PURPLE, DOUBLE YELLOW, DOUBLE WHITE, each ................ 


\section{- ORNAIIETAL FoLIAGE PLANTS}

Have become very popular. The following varieties can be readily grown from seed, and produce a fine effect for the adornment of the flower garden, terraces, pleasure grounds, \&c.

AMARANTHUS. Showy plants, some with ornamental foliage and very effective in groups.

\$6 CAUDATUS. (Love lies Bleeding) Blood red flowers, 3 to 4 feet..............................................................

"HYPOCHONDRIACUS. (Prince's Feather) Showy; 4 to 5 feet...............................................................

"MELANCHOLICUS. (var. ruber.) Introduced by Mr. Veitch, from Japan. Its habit is very compact, height 12 to 18 inches, with striking blood-red foliage. A very fine-foliaged bedding plant..................................................

"TRI-COLOR. Leaves red, yellow and green; very handsome and showy; known also as "Joseph's Coat." ...................

“ GIGANTEUS-Chinese.........................................

CANNA or INDIAN SHOT, The Cannas are a stately species of plants, highly ornamental, producing a very rich and Oriental effect, by their large, broad, massive foliage, terminated by racemes of crimson or scarlet variously lobed flowers. Soak the seed in hot water before planting, take up the roots before frost, and preserve in a warm cellar or room.

" INDICA. Bright red. CUBENSIS. Orange and red, each WARSCEWICZII. Blood red. GIGANTEA. Large scarlet. Each....................................................

“ Twelve choice varieties.................................... \$

EUPHORBIA VARIEGATA. Showy white and green foliage, about 2 feet high, very ornamental for planting in masses with Amaranthus Melancholicus, Tri-color, or Perilla nankinensis...................................................

MAIZE. STRIPED LEAVED JAPANESE grows to a height of 4 to 5 feet. It is beautifully and evenly striped, and ribboned with alternate stripes of green and white, and in its earlier stages of growth, is also striped with rose color. Nothing in the way of a foliage plant can exceed in gracefulness and beauty a group of this plant.

5

PERILLA NANKINENSIS. A neat ornamental plant, with dark purple foliage, very striking..................................

" OCYMOIDES. A variety of the above..........................

RICINUS SANGUINES. Showy and effective, growing from six to eight feet high, blood-red stalks and seed-pods..............

"TRI-COLOR. Dark green and brown spotted, the stalk is reddish brown..................................................

" AFRICANUS ALBIDUS. Contrasts finely with the above....

YUCCA FILAMENTOSA. Exceedingly stately and highly ornamental hardy plant, requires several years to grow to perfection. 


\section{ORNAMENTAL GRASSES. * \\ FOR BOUQUETS AND DECORATIVE GROUPS.}

Agrostis Pulchella.

" Nebulosa.

Arundo Donax versicolor.

(Ribbon Grass)

Avena Sensitiva or Animated Oats.

Briza Maxima, Quaking Grass. " Gracilis.

Coix Lachryma. (Job's Tears)

Elymus Hystrix

Stipa Elegantissima $10 \mathrm{cts}$.

Eragrostis Namaquensis.

"Senegalensis.

Grangea Maderaspatana.

Gynerium Argenteuni. (Pampas Grass) $25 \mathrm{cts}$.

Lamarkia Aurea.

Sorghum Saccharatum.

Stipa Pinnata. (Feather Grass)

\section{SEEDS OF GREEN-HOUSE PLANTS.}

Florists' Flowers, ETc.-Those marked with a * are suitable for bedding out in the summer. Price, 25 cents per paper, except when noted :-

Acacia, choice mixed.

Argyranthemum frutescens.

Azalea indica.

Auricula, very choice imported.

Bonapartea juncea.

Calceolaria, spotted hybrid, 50 cts.

* Erythrina Crista galli. (Coral Plant.)

Erythrina Hendersonii. " Laurifolia.

Epacris, choice varieties.

FERN, choice varieties.

" superb dwarf, spotted varieties, 50 cts.

Calceolaria, rugosa shrubby, 50.

Chrysanthemum, Chinese.

Cineraria, choice Hybrid.

Fuchsia, or Ladies' Ear-drop, mixed.

* Geranium, fine scarlet varieties. Gloxinia, choice mixed, 50 cts.

Habrothamnus elegans.

$$
\text { “ " Dwarf, } 50 .
$$

Clianthus Damperii, 50 cts.

* Heliotrope, Peruvianum.

Cyclamen Persicum and European.

* Heliothrope, Roi des Noirs.

* Lantana, newest varieties, a fine bedding plant.

Pelargonium, finest fancy and large-flowered.

PRIMULA SINENSIS, FIMBRIATA CERMESINA SPLENDENS.-

Very large flowers, bright velvet-like crimson. This new variety surpasses all other varieties of the Chinese Primrose by its brilliant color and large size, 50 cts.

Primula Sinensis, Rosea Fimbriata, fringed Chinese Primrose.

“ $\quad$ Flba “ $\quad$ Eimbriata Alba, Rubra St
" $\quad$ Erecta Superba. (Novelty)
Coralea, Blue Passion flower.
Edulis.
Splendens, scarlet sage.
Coccinea Splendens, freo-bloomer.
Pumila, dwarf.
Patens, superb blue.

Tropæolum Lobbianum, Green-house climber.

" " Giant des battailles, dark orimson.

" " Tricolor grandiflorum. 


\section{FLOWER SEEDS IN ASSORTMENTS.}

The following are principally imported direct from Prussia, and will be found very choice. They are sold in the original packages at the price named. Each variety or color separate in the package.

ANTIRRHINUM, ................................ 12 varieties, $\$ 100$

ASTERS, finest quilled,.......................... 24 " 150

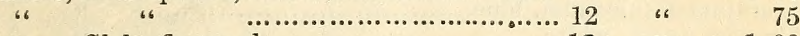

" Globe-flowered,.......................... " $12 \quad 100$

" DWARF BOUQUET, ..................... "12 " 100

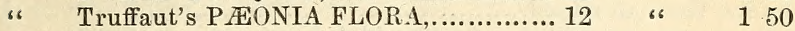

" NEW IMBRIQUE POMPONE,........... "12 " 100

" COCARDEAU OR CROWN,............. "12 " 100

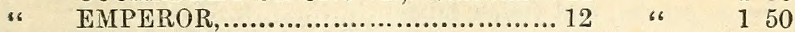

"LARGEF-LOWERED ROSE, $($ new, $\ldots . .12$ " $12 \quad 150$

BALSAM, Double Camellia-Flowered,.............. 12 "6 150

"6 DWARF " "............... 12 6 100

“ NEW FRENCH ROSE,.................... 12 « 150

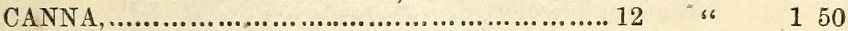

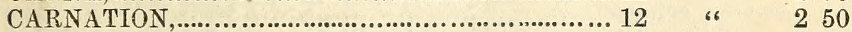

COCKSCOMBS, fine German,...................... 12 " 100

IMMORTELLE, or Everlasting Flower,............ I2 " " 1 ก0

$$
\text { "6 "6 .............. } 24
$$

HOLLYHOCKS, superb double English,............ 8

LARKSPUR, HYACINTH-FLOWERED,.......... 12 CONSOLIDA, branching,............ 8

MARIGOLDS, fine double,......................... 12

'PINKS, ................................................. 12

POPPY, Double Carnation, ........................ 12

" New Pæoniaflora,......................... 12

SENECIO ELEGANS, Double Jacobea,............. 8

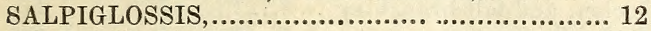

SCABIOSA MAJOR, ............................... 6

"6 NANA,................................ 6

STOCKS, large flowered, ten weeks, .............. 12

"6 "6 6 "............... 8

“ PERPETUAL FLOWERING, ten weeks, 10

“ AUTUMNAL.............................. 12

“ EMPEROR, or PERPETUAL, .......... 10

“ BROMPTON, or WINTER,.............. 12

WALL-FLOWER, fine German Double,.............. 10

ZINNIA ELEGANS, New Double,.................. 8

GREEN-HOUSE PLANTS, choice selection,........ 25

FERNS,.......................................... 12

ORNAMENTAL-LEAVED PLANTS, ............. 12

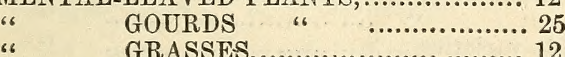

GRASSES,$\ldots \ldots \ldots \ldots \ldots \ldots \ldots \ldots \ldots \ldots . \ldots \ldots$
PHLOX DRUMMONDII, ............................. 8

PRIMULA CHINENSIS, .............................. 10 


\section{ANNUALS BY WEIGHT.}

The following are offered by quantity, and are exceedingly showy and effective for massing in beds, borders, marginal lines or ribbons; also as large groups for front effect in shrubberies, \&c., and in covering large or blank spaces, or beds.

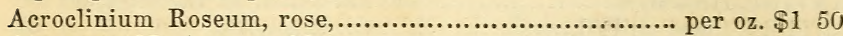

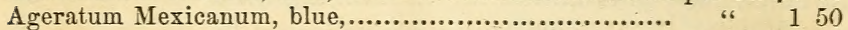

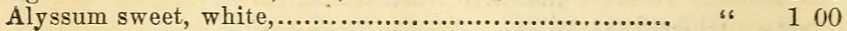

Amaranthus giganteus, crimson, ............................. " " 100

Asters, German mixed,.................................... " “ 100

" " quilled and pyramidal,. ......................

Balsams, dwarf camellia-flowered, ..........................

Cacalia, scarlet, and yellow mixed, .........................

Calliopsis-marmorata, tinctoria, and Drummondii,.........

Candytuft, white, purple and çrimson, .....................

Cockscomb, crimson and mixed varieties, ...................

Convolvolus Major, morning glory, mixed,................

“ . Minor or Tricolor................................

Cypress vine, crimson, .....................................

Dianthus Chinensis, extra double China Pink...............

Erysimum Peroffskianum, orange ............................

Eschscholtzia-crocea, orange, California Poppy............

Euphorbia variegata, green and white, showy ..............

Gilia tricolor...................................................

Gomphrena globosa, or Globe amaranth, crimson and white,

Helianthus nanus, dwarf double sunflower....................
“" majus, tall
“

................. per $1 \mathrm{lb}$.

Ipomœa, coccinea, star morning glory,...................... per oz.

150

200

100

100 60

100 30 50 80

150 60 80

"، nova striata, new striped,.......................

Larkspur, dwarf rocket, and tall branching,.............

Marigold, dwarf and tall varieties,........................

Mignonette, sweet-scented, ................................

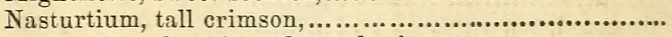

"، dwarf searlet and crimson,....................

Enothera grandiflora, Evening primrose,..................

Phlos Drummondii, mixed,

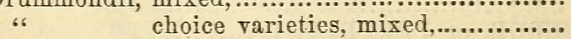

Petunia, mixed varieties, ................................... " choice mixed hybrid,

Perilla Nankinensis, dark purple foliage.................... " Ocymoides

Portulaca, choice mixed colors, ..............................

Sweet Peas, choice colors, mixed......................... Thunbergia, " " $\quad$ "........................

Zinnias, fine double varieties, $\ldots \ldots \ldots \ldots \ldots \ldots \ldots \ldots \ldots \ldots \ldots . . . \ldots \ldots$ 


\section{HINTS TO GARDENERS.}

"A place for every thing, and every thing in its place," is an adage generally more honored in the breach than in the observance; and yet it is one which has a peculiar importance for the Farmer and Horticulturist. To have the tools belonging to a garden or farm so arranged that the hand can be laid on them at any moment, is always desirable. It saves not only time, but it saves vexation, and very frequently irreparable loss. We have prepared a diagram, which will explain our meaning more clearly than words. The adoption of such a plan will repay the cost and trouble, ten times over, in the course of a single year.

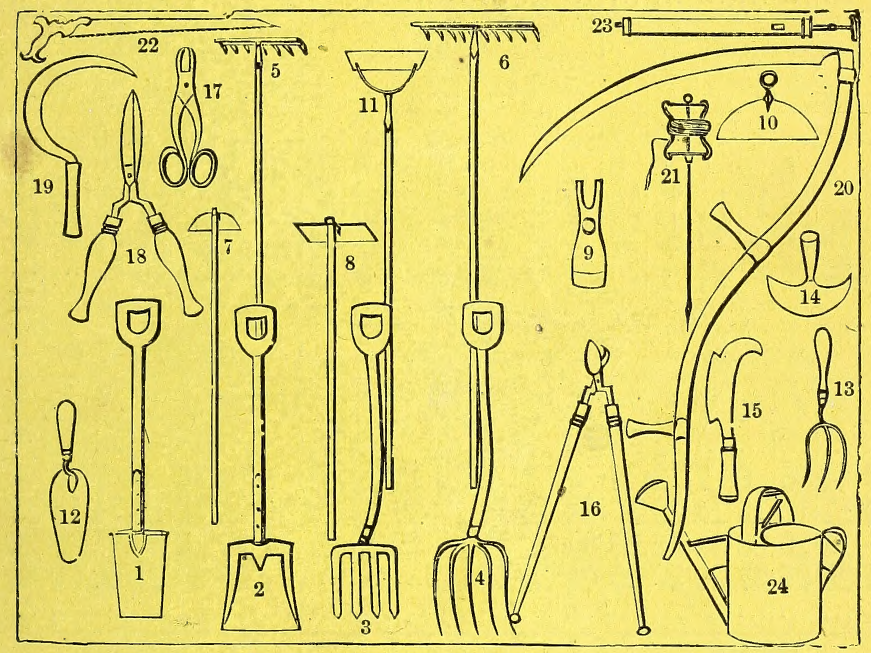

No. 1, of the diagram, represents the ordinary cast steel Garden Spade. No. 2, a cast steel Shovel, D handled, for taking up rubbish, \&c. No. 3, steel Digging Fork, indispensable to every garden. No.4, steel Manure Fork. No. 5, steel Garden Rake, No. 6, Lawn Rake. No. 7, Turnip, or Onion Hoe. No. 8, cast steel Garden Hoe. No. 9, steel-pronged Hoe. No. 10, Crescent Socket Hoe. No. 11, Scuffle, or Dutch Hoe No. 12, Garden Trowel. No.13, steel Weeding Fork. No. 14, cast steel Grass Edging Knife. No. 15, short-handled Bill, or Brier Hook. No. 16, strong long-handlec Pruning Shears. No. 17, Pruning Scissors. No. 18, Hedge or Box Shears. No. 19, Grass Hook. No. 20, Lawn Scythe. No. 21, Garden Reel and Line. No. 22, Pruning Saw. No. 23, Brass Syringe. No. 24, Watering Pot.

All these tools should be of the very best quality-the best being the cheapest, always. Our stock of all articles needed for Gardener's use, will be found to be of the most complete character, and of the very best quality. 


\section{DREER'S GARDEN CALENDAR.}

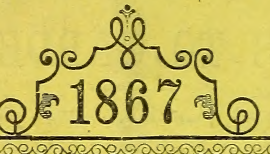

\begin{tabular}{|c|c|c|c|c|c|c|c|c|c|c|c|c|c|}
\hline \multicolumn{7}{|c|}{ JANUARY. } & \multicolumn{7}{|c|}{ MAY. } \\
\hline$S$ & $\boldsymbol{M}$ & $T$ & $\boldsymbol{W}$ & $\boldsymbol{T}$ & $\boldsymbol{F}$ & $S$ & $S$ & $M$ & $T$ & 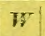 & $T$ & $F$ & \\
\hline & $\begin{array}{r}7 \\
14 \\
21 \\
28\end{array}$ & $\begin{array}{r}\frac{1}{8} \\
8 \\
15 \\
22 \\
29\end{array}$ & $\begin{array}{r}2 \\
9 \\
16 \\
23 \\
30\end{array}$ & $\begin{array}{r}3 \\
10 \\
17 \\
17 \\
24 \\
31\end{array}$ & $\begin{array}{r}4 \\
11 \\
18 \\
25\end{array}$ & $\begin{array}{r}5 \\
12 \\
12 \\
19 \\
26 \\
\ldots\end{array}$ & $\begin{array}{r}5 \\
12 \\
19 \\
26 \\
26\end{array}$ & $\begin{array}{r}6 \\
6 \\
13 \\
20 \\
20 \\
27\end{array}$ & $\begin{array}{r}\ldots \\
7 \\
14 \\
21 \\
28 \\
\ldots\end{array}$ & $\begin{array}{r}1 \\
8 \\
15 \\
25 \\
22 \\
29 \\
\ldots\end{array}$ & $\begin{array}{r}2 \\
9 \\
16 \\
23 \\
30 \\
\ldots\end{array}$ & $\begin{array}{l}10 \\
17\end{array}$ & \\
\hline \multicolumn{7}{|c|}{ FEBRUARY. } & \multicolumn{7}{|c|}{ JỤT. } \\
\hline & $M$ & $T$ & $w$ & $\boldsymbol{T}$ & $F^{\prime}$ & $S$ & 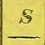 & II & $\underline{T}$ & $W$ & $T$ & $\boldsymbol{F}$ & \\
\hline & $\begin{array}{r}4 \\
11 \\
18 \\
18 \\
25\end{array}$ & $\begin{array}{r}5 \\
12 \\
19 \\
19 \\
26\end{array}$ & $\begin{array}{r}\cdots \\
6 \\
13 \\
20 \\
20 \\
27\end{array}$ & $\begin{array}{r}\cdots \\
7 \\
14 \\
21 \\
28\end{array}$ & $\begin{array}{r}\therefore 1 \\
8 \\
15 \\
22\end{array}$ & $\begin{array}{r}2 \\
9 \\
16 \\
23\end{array}$ & $\begin{array}{r}\ldots \\
2 \\
9 \\
16 \\
163\end{array}$ & $\begin{array}{r}\ldots \\
3 \\
10 \\
17 \\
24 \\
24\end{array}$ & $\begin{array}{r}\ldots \\
4 \\
11 \\
18 \\
25 \\
25\end{array}$ & $\begin{array}{r}5 \\
12 \\
12 \\
19 \\
29 \\
26\end{array}$ & $\begin{array}{r}6 \\
6 \\
13 \\
90\end{array}$ & $\begin{array}{r}7 \\
74 \\
14 \\
97\end{array}$ & \\
\hline & \multicolumn{6}{|c|}{ MARCH, } & \multicolumn{7}{|c|}{ JULY. } \\
\hline & & & 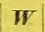 & & $F$ & & N & $M$ & & $m$ & $\boldsymbol{T}$ & 7 & \\
\hline
\end{tabular}

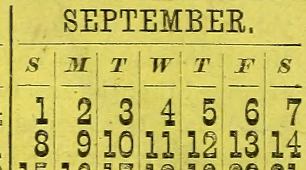

15161718192021 22232425262728 $2830 \ldots \ldots \ldots \ldots \ldots$

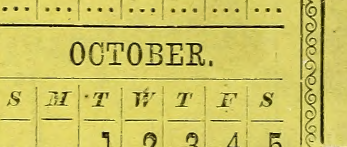

\begin{tabular}{llllllllllllll}
\hline & $M$ & $T$ & $W$ & & $F$ & $S$ & $S$ & $M$ & $T$ & $W$ & $T$ & $F$ & $S$
\end{tabular}

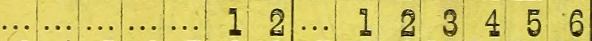

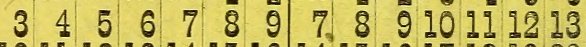
10111213141516 17181920212223 24252627282930 31 14151617181920 21222324252627 $28293031 \ldots \ldots \ldots$ 6 7. 8 9 91112 13141516171819 20212223242566 $2728293031 \ldots .$. ... NOVEMBER. \begin{tabular}{ll|l|l|l|l|l|l|}
$S$ & $\boldsymbol{M}$ & $\boldsymbol{T}$ & $\boldsymbol{W}$ & $\boldsymbol{T}$ & $\boldsymbol{F}$ & $\boldsymbol{S}$ \\
\hline
\end{tabular} ............. 12 $\begin{array}{lllllll}3 & 4 & 5 & 6 & 7 & 8 & 9\end{array}$ 10111213141516 17181920212223 24252627282930 $\begin{array}{cccccc} & \ldots & \ldots & \ldots & \ldots & \ldots\end{array}$

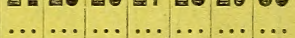
APRIL, AUGUST. \begin{tabular}{l|l|l|l|l|l|l|l|l|l|l|l|l|l|}
\hline $\boldsymbol{S}$ & $\boldsymbol{M}$ & $\boldsymbol{T}$ & $\boldsymbol{W}$ & $\boldsymbol{T}$ & $\boldsymbol{F}$ & $\boldsymbol{S}$ & $\boldsymbol{S}$ & $\boldsymbol{M}$ & $\boldsymbol{T}$ & $\boldsymbol{W}$ & $\boldsymbol{T}$ & $\boldsymbol{F}$ & $\boldsymbol{S}$ \\
\hline
\end{tabular} DECEMBER.

F 133456 F 8 9 1011 1213 I 151617181920 s 222324252627 $12930 \ldots . . . . . .$. $\begin{array}{rrrrrrr}\ldots & \ldots & \ldots & \ldots & 1 & 2 & 3 \\ 4 & 5 & 6 & 7 & 8 & 9 & 10 \\ 11 & 12 & 13 & 14 & 15 & 16 & 17 \\ 18 & 19 & 20 & 21 & 22 & 23 & 24 \\ 25 & 26 & 27 & 28 & 29 & 30 & 31\end{array}$

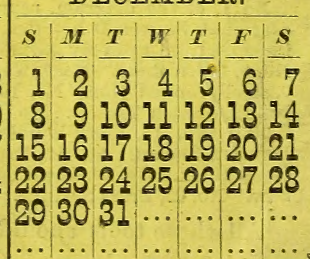

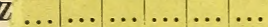

